\title{
THE KUMMITSOIVA KOMATIITE COMPLEX AND ITS SATELLITES IN NORTHERN FINLAND
}

\author{
MATTI SAVERIKKO
}

\begin{abstract}
SAVERIKKO, MATTI 1983: The Kummitsoiva komatiite complex and its satellites in northern Finland. Bull. Geol. Soc. Finland 55, 2, $111-139$.

The Kummitsoiva komatiite complex and its satellites, regarded either as Archean or Proterozoic in age, consist principally of amphibole-chlorite rocks corresponding chemically to basaltic komatiite of the Geluk type in South Africa. The rocks are mainly pyroclastic and vary from agglomerates to tuffs with epiclastic amphibole-chlorite debris. The lavas are massive flows, autobrecciated lavas and, sometimes, pillow lavas. The Kummitsoiva complex also contains komatiites proper as a few serpentine-olivine rock interlayers made up of lavas, and of pyroclastic and epiclastic rocks.

Erupting basaltic komatiite lavas were mainly very viscous whereas those of the komatiites proper were fluidal.

The Kummitsoiva complex, originally a large isolated volcano, erupted through a volcanic conduit and a fissure net. The satellites deposited around and upon separate volcanic vents. They were all located at the margin, or on islands of an interior bas in in a continental environment. Euxinic-epiclastic sedimentation preceded the komatiite eruptions, and mafic or intermediate volcanism took place or continued after the explosive komatiite volcanism.

The alignment of the volcanic vents implies a geotectonic fault in a northwesterly direction coeval with the euxinic-epiclastic sedimentation. Displacements of fault blocks can be inferred from tectonicstratigraphic features.

The komatiites belong to the upper part of the Lapponian supracrustal sequence, which forms a greenstone belt-like rock association in the schist area of central Lapland in the Baltic Shield.
\end{abstract}

Key words: basaltic komatiite, komatiite, paleovolcanism, paleotectonism, petrography, geochemistry, Lapponian stratigraphy, central Lapland, Baltic Shield, Precambrian.

Matti Saverikko: Department of Geology, University of Helsinki, Snellmaninkatu 5, SF-00170 Helsinki 17, Finland.

\section{Introduction}

The pyroclastic komatiite investigated is called the Kummitsoiva komatiite complex after a hill lying in the middle of the area and in the vicinity of the complex there are also two satellites.
Located in the Baltic Shield, the komatiites are part of the schist area of central Lapland (Fig. 1) previously regarded as Proterozoic (Simonen 1960a, 1960b, 1971 and 1980). Simonen (1980) considered that the schist area is composed mainly of Karelian schists and included it in the lower part of the 


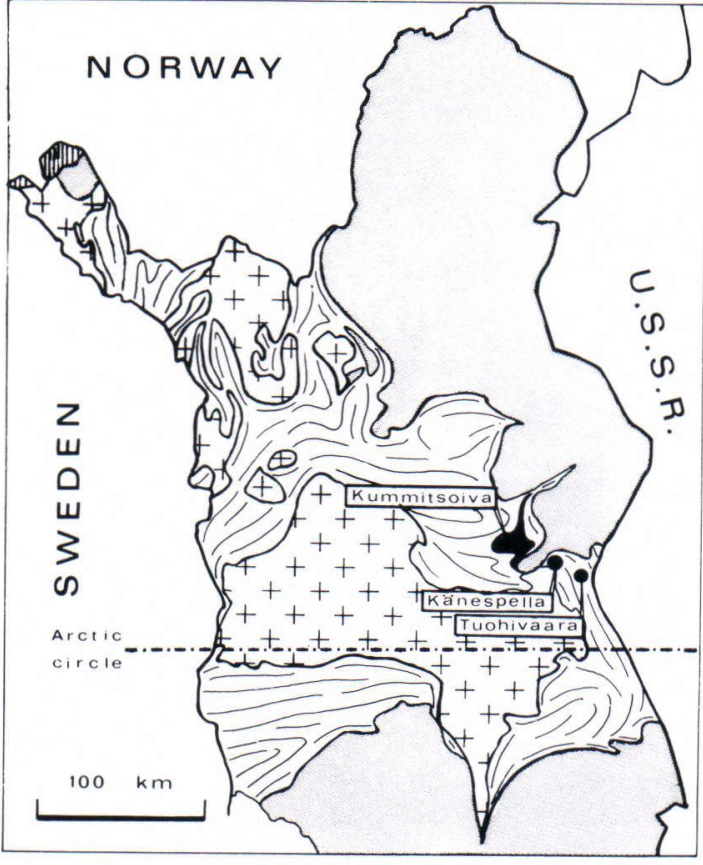

1. $\square$ Pre-Svecokarelian basement:2. karelian schists: 3 . komatiites: $4 .+$ sveco. karelian plutonic rocks; 5 . $\mathbb{\| m | l | l | l}$ Caledonian rocks

Fig. 1. Location of the studied pyroclastic komatiites on a geological map of northern Finland simplified after Simonen (1980).

Svecokarelian supracrustal sequence separated by a marked unconformity from the Archean basement. The area contains epicontinental Jatulian and flyschoidal Kalevian metasediments characteristic of the Karelian supracrustal sequence (Simonen 1980). But Silvennoinen et al. (1980) suggest that the bulk of the schist area is Archean in age and makes up the Lapponian supracrustal sequence (3100-2600 $\mathrm{Ma}$ in age), which is older than the Karelian supracrustal sequence (2600-2000 $\mathrm{Ma}$ in age). Lapponian rocks constitute greenstone belt-like rock associations (Silvennoinen et al. 1980) and thus resemble the Kuhmoian schists (2800$2600 \mathrm{Ma}$ in age) in eastern Finland (Simonen 1971), which also include komatiites (Blais et al. 1979; Hanski 1980; Auvray et al. 1982).
The Kummitsoiva komatiite complex is the core of the Jauratsi greenstone belt, named by Gaál et al. (1978), whereas the satellitic komatiites at Känespella and Tuohivaara lie in the Salla greenstone belt (Gaál et al. 1978). Silvennoinen et al. (1980) considered the undated komatiites to be Upper Lapponian metavolcanic rocks (2750-2600 $\mathrm{Ma}$ in age) but this hypothetical interpretation is based on stratigraphic generalizations from some key areas outside the area investigated.

The ultramafic metavolcanic rocks have been investigated previously by Mikkola (1937, 1941), Rieck et al. (1967), Mielikäinen (1979), Manninen (1981), and Räsänen (1983). The rocks were established as komatiites by Mutanen (1976) and Manninen (1981).

Vigorous prospecting in the Kummitsoiva area, directed initially to the Jauratsi iron ore deposit, was started by Rautaruukki Oy in the 1960 s and continued by Lapin Malmi.

\section{Geological setting}

The Jauratsi greenstone belt lies in a triangular tectonic basin in the Pre-Svecokarelian basement. Excluding its northern tapered part outside the area investigated, the basin has gently dipping margins. Only the eastern boundary is exposed on an erosion surface. The Salla greenstone belt, which lies on the Pre-Svecokarelian basement, is a shallow tectonic basin with an arc-shaped depression at its eastern margin filled with Salla greenstone.

The lithological features of these greenstone belts differ little (Fig. 2), and their stratigraphic suites are almost uniform (Fig. 3 ). As a matter of fact, they constitute an interconnected greenstone-metasediment association that is probably the southeastern part of the greenstone belt composed of Lapponian supracrustal rocks. Thus, the Jauratsi and Salla greenstone belts can be used as geographical terms. 


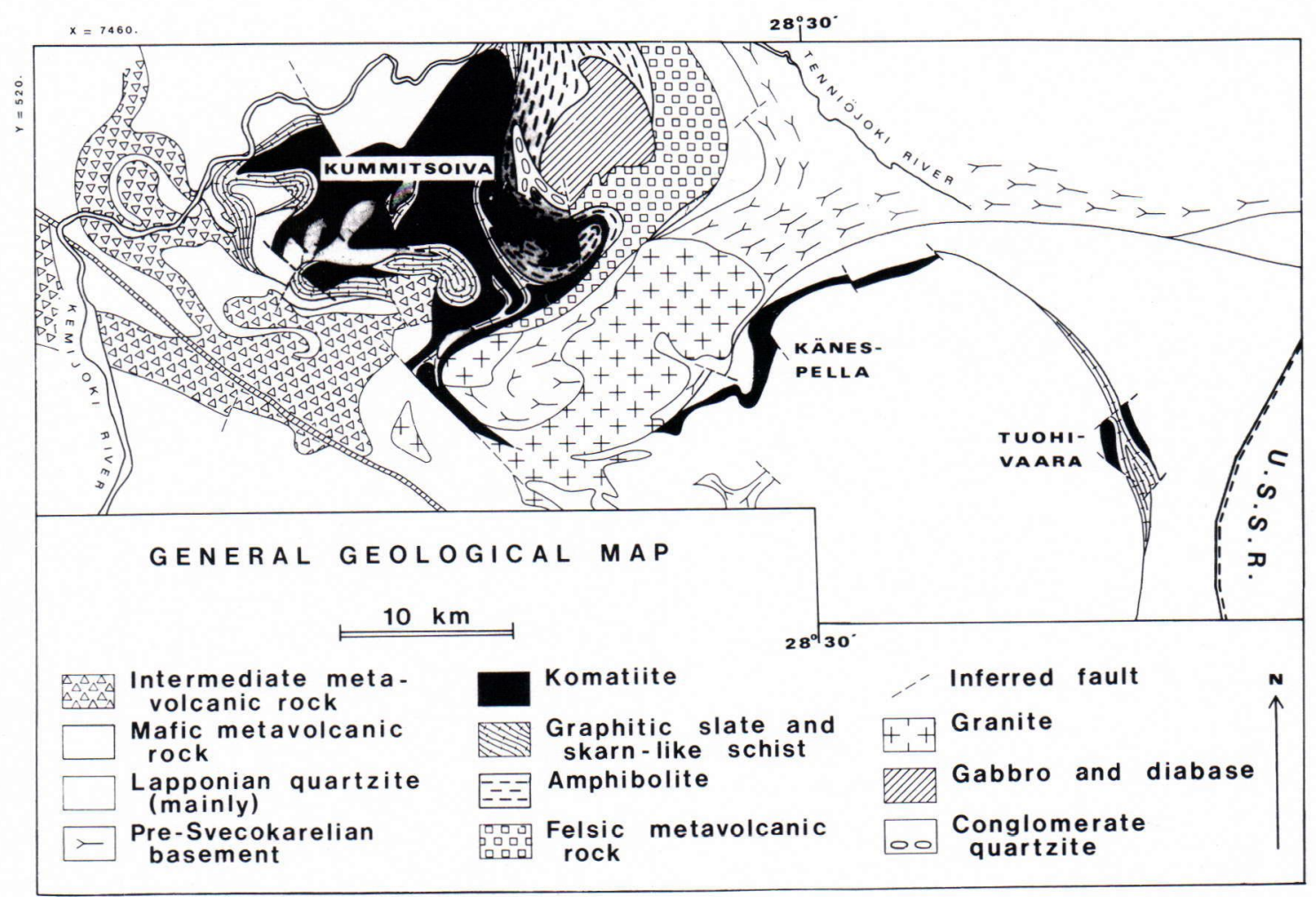

Fig. 2. General geological map of the Jauratsi and Salla greenstone belts.

The basement complex consists of trondhjemitic orthogneiss (Manninen 1981), foliated granodiorite, and granite and banded biotite gneiss, such as in the other Pre-Svecokarelian basement-gneiss areas (Simonen 1980). The basal arkoses in the basement grade into Lapponian quartzite, which makes up the marginal zones of the greenstone belt (Mikkola 1941). The Lapponian quartzite is a calcium silicate-bearing arkose quartzite with intercalated orthoquartzite, sericite schist and skarn (Mikkola 1941; Manninen 1981). Polymictic brecciaconglomerates have been deposited in the upper part of the quartzite together with an uralitic greenstone interlayer.

The bulk of the Salla greenstone overlying the Lapponian quartzite is a mafic metavolcanic rock but it has intermediate and felsic interlayers and ultramafic parts. The interlayers consist of dacitic and rhyolitic lavas and crystal tuffs, at least in the Jauratsi greenstone belt (Manninen 1981). Also present is an amphibolite presents an iron-rich tholeiitic basalt (Manninen 1981).

Overlying the amphibolite, the Salla greenstone and the Lapponian quartzite, and separated from them by an unconformity, is a heterogeneous graphitic slate zone. As well as skarn-like schists it contains interlayers of jaspilitic iron ores and sulphide slates (Rieck et al. 1967; Lehto and Niiniskorpi 1977), cherts, dolomites (Manninen 1981), metagreywackes (Rieck et al. 1967) and mica schists. Many of the rocks contain a few pebbles or intraclasts and have conglomeratic parts. A paraconglomerate at the top of the stratum, close to the hill Kummitsoiva, contains peb- 


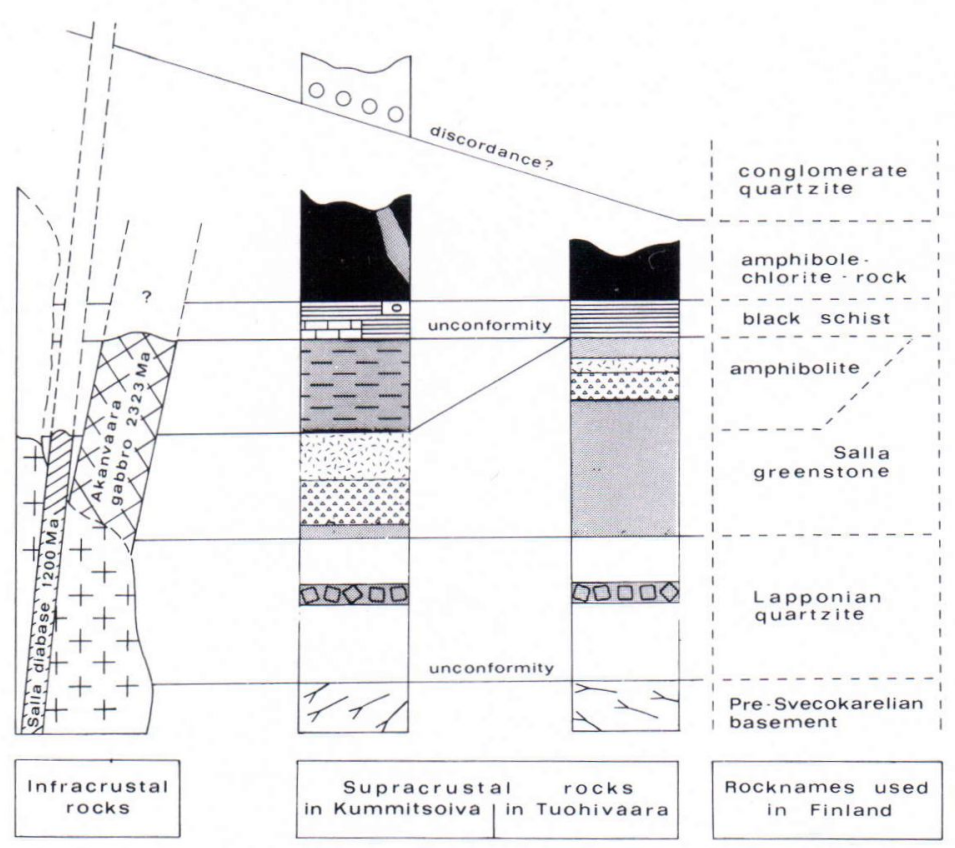

\footnotetext{
Symbols :

1. $\square$ Granite gneiss : $2 . \square$ Arkose quartzite and orthoquartzite: 3. 000 Uralitic greenstone: $4 . \square$ Mafic metavolcanic rock: 5 . Intermediate metavolcanic rock: 6. Felsic metavolcanic rock ; 7 Amphibolite : 8. 差质 Skarn-like schist: 9. Volcanic conglomerate: 11. Komatiite: 12 . 00 conglomerate quartz. ite : 13. + Granite
}

Fig. 3. Stratigraphic columns of the rock suites in the Kummitsoiva (the Jauratsi greenstone belt) and Tuohivaara areas (the Salla greenstone bles, cobbles and boulders of the above rocks, particularly the volcanic ones, in a hornblende-rich matrix. It grades into a pyroclastic komatiite. The uppermost strata of the graphitic slate zone are slumped.

The komatiites are amphibole-chlorite rocks, mainly agglomeratic in origin (Mikkola 1941), but the agglomerates alternate with volcanic breccias, tuffites and lavas (Manninen 1981). They constitute the youngest metavolcanic rock unit as relicts cut by the erosion surface. The Kummitsoiva komatiite complex, however, is penetrated by a mafic (not analysed) volcanic neck.

The Jauratsi greenstone belt includes a conglomerate quartzite (Manninen 1981) that differs tectonically from its surroundings and is composed of polymictic conglomerates, a metagreywacke and a sericite quartzite (Manninen 1981). It may be the youngest supracrustal rock suite (Manninen 1981) and lithologically comparable with the quartzite conglomerates included in the Karelian supracrustal sequence by Silvennoinen et al. (1980).

Plutonic magmatic activity disturbed the supracrustal rocks only slightly. The Akanvaara gabbro, dated by O. Kouvo at $2323 \mathrm{Ma}$, intersects at least the iron-rich tholeiitic basalt and older rocks (Manninen 1981). Pegmatitic microcline granites, intruded mainly into the Pre-Svecokarelian basement com- 
Fig. 4. Lithologic map of the Kummitsoiva komatiite complex, which is flat-lying and upfacing with the exception of its marginal zones, which are folded tightly together with graphitic slate and skarn-like schist.

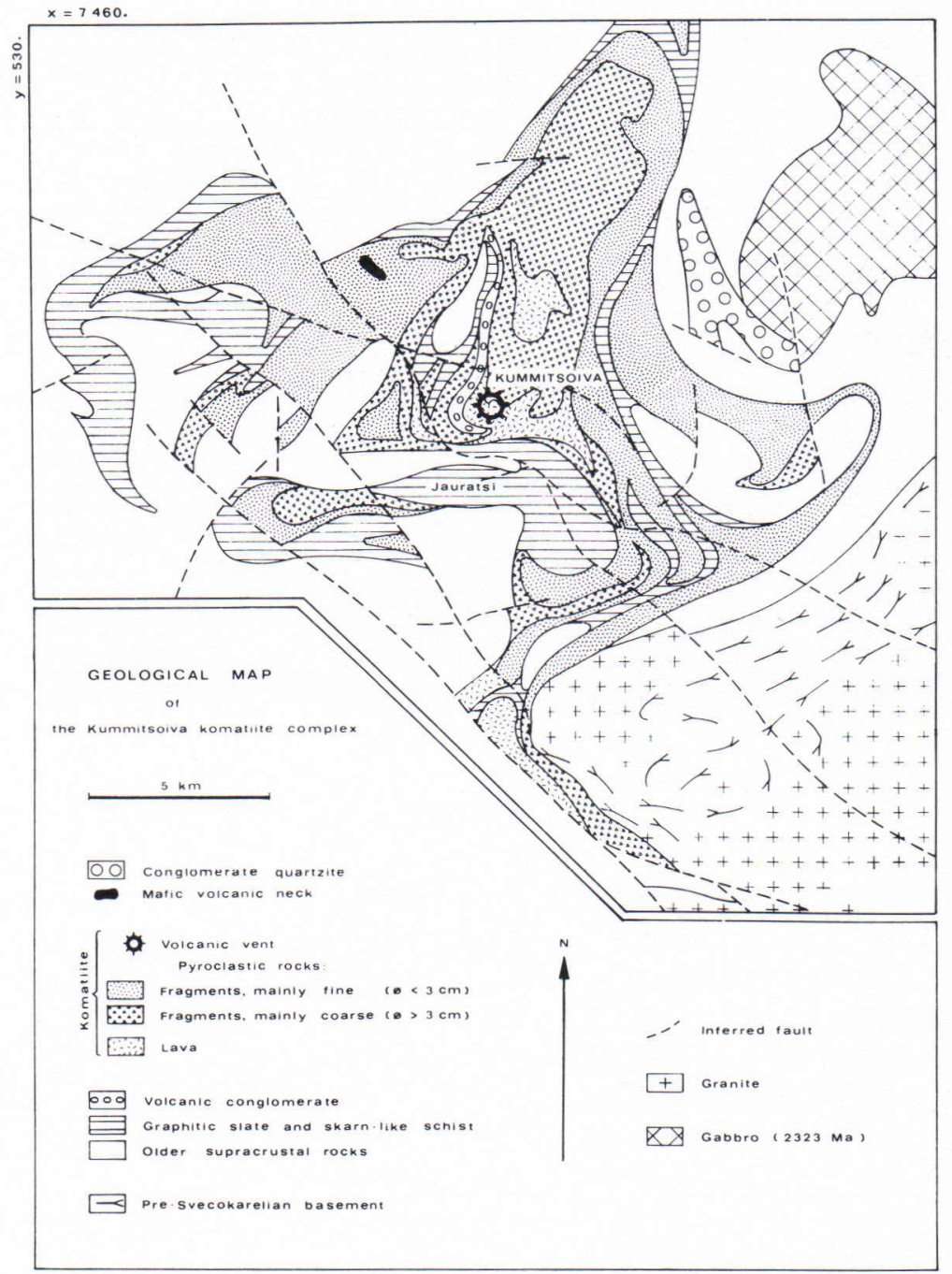

plex, have some satellites in the marginal zones of the Jauratsi and Salla greenstone belts. It has been suggested that they are products of the partial anatexis of the basement complex that took place about 1800 Ma ago (Lauerma 1982). The youngest magmatic rock in the area is the Salla diabase, dated by O. Kouvo at $1200 \mathrm{Ma}$, which intersects the Lapponian quartzite, the Salla greenstone and granites (Lauerma 1967a, 1967b).

\section{Komatiite exposures}

The Kummitsoiva komatiite complex and its satellites are lithologically uniform and their rocks are considered jointly of the basis of the special features of the exposures. Since the description of pyroclastic komatiites are not common, attention is focused chiefly on the description of primary volcanic structures. The volcanological terms used are by 


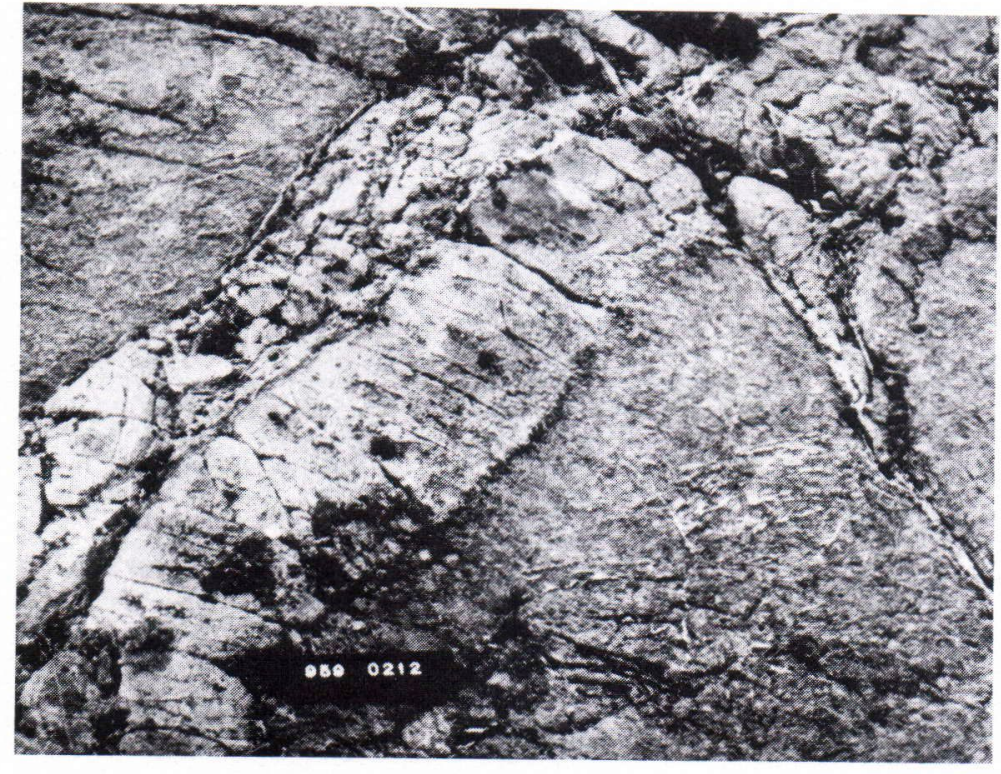

Fig. 5. A 20-cm-thick lava dyke cutting a coarse-grained tuff and dipping gently towards the lower right-hand corner of the photograph. Northwestern margin of the Kummitsoiva komatiite complex. The index plate is $16 \mathrm{~cm}$ long. Photo by the author.
Macdonald (1972) and Williams and McBirney (1979). The pyroclastic rocks are named according to the generally accepted classifications of Fisher $(1961,1966)$, but the compositional nomenclature is based on the classification of Cook (1965).

The bulk of the lavas on Kummitsoiva are in the middle of the mainly pyroclastic komatiite complex (Fig. 4). A gravimetrically established volcanic conduit $(\emptyset>0.5 \mathrm{~km}$ ) also exists on Kummitsoiva. Lava flows are scattered throughout the outer zones of the complex and lava dykes cut older rocks and the lower part of the complex (Fig. 5). A 150m-thick lava dyke intersects a mafic metavolcanic rock at the southwestern margin of the complex and may include pyroclastic parts. Lava flows grade into coarse-grained pyroclastic rocks which lie around and partly upon lavas. The outer zones of the complex consist of fine-grained pyroclastic rocks interbedded in many places with transitional boundaries. As a result of local small-scale changes, the limits of the rocks on the map are a matter of conjecture in some places.

The komatiite complex was deposited on a stratum composed mainly of graphitic slate and skarn-like schist and contains these metasediments as intercalations in its lower part. It was extruded on amphibolite and on mafic metavolcanic rock, probably Salla greenstone, and its contact with these rocks is sharp. Its northwestern margin seems to be in contact with Lapponian quartzite. But the contact shown on the map between the komatiite and the Pre-Svecokarelian basement is only inferred because a graphitic slate, an amphibolite and a mafic metavolcanic rock were discovered by diamond drilling beneath the komatiite near the rock boundary.

The complex has been measured in its northern part with audiomagnetotelluric sounding to be $700 \mathrm{~m}$ thick but the thickness may be about $1-2 \mathrm{~km}$ at Kummitsoiva.

The satellitic komatiite at Känespella includes lapilli tuffs and agglomerates, but 
lavas form a breccia-bearing volcanic neck as a steep-sided rocky hill $(\emptyset 200-350 \mathrm{~m})$. The komatiite is extruded on an arkosic orthoquartzite and on the Salla greenstone (Fig. 6). Electrically conducting rocks in its marginal zones are regarded as graphitic slates, and a dolomitic skarn has been discovered by diamond drilling in its hanging wall.

The satellitic komatiite at Tuohivaara is present as two adjoining exposures (Fig. 6). Its lower part contains tuffs and lapilli tuffs, but its upper part consists mainly of lapillistones and agglomerates. One of the small lava flows has the shape of a volcanic neck (0 20-30 m). The komatiite was deposited on the graphitic slate, but it also lies on the Salla greenstone, being separated from it by a sedimentary breccia. Graphitic slates exist as thin interbeds in the lower part of the tuffaceous komatiite. The satellitic komatiite is $300-350 \mathrm{~m}$ thick.

\section{Lavas}

The rocks, originally lavas, are present as amphibole-chlorite rocks with the exception of a few serpentine-olivine rock interlayers in the lower part of the Kummitsoiva complex.

The serpentine-olivine rocks are dark brown with dark grey fresh surfaces. The medium-grained and massive lava flows have fine-grained margins, and their joint patterns show the presence of flow-like structures. The lavas grade into lapillistones.

The amphibole-chlorite rocks are light brown or brownish green, but their fresh surfaces are greenish grey. The lavas are usually massive and homogeneous and, with the exception of the fine-grained rocks, slightly oriented or flow-textured, sometimes with a few amygdules $(\emptyset 0.1-1 \mathrm{~cm})$. The amygdules filled with carbonates are spherical and partly rusty, but the ones filled with tremolite-
Fig. 6. Lithologic maps of the satellitic komatiites at Känespella and Tuohivaara. The one at Känespella lies in a shallow open syncline but the one at Tuohivaara lies in two adjoining synclines, which are folded tightly and overturned towards the west.

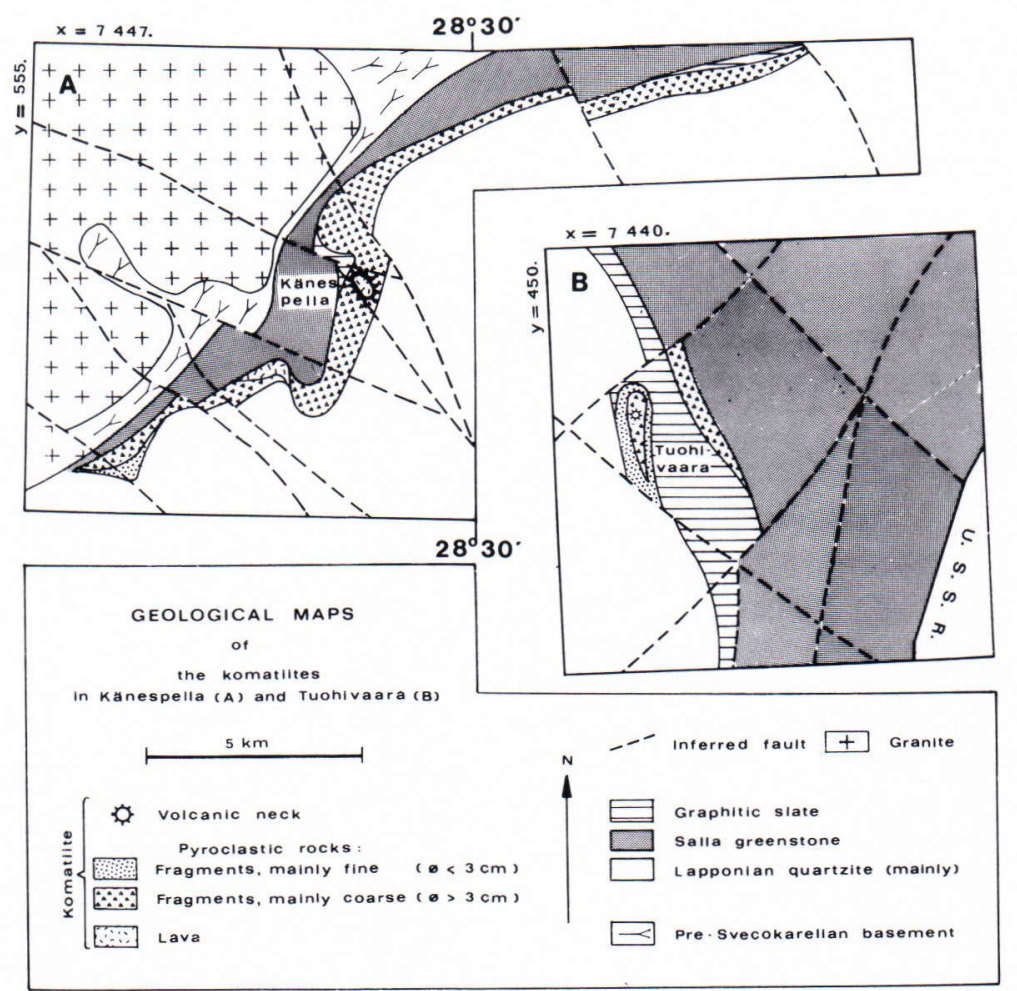




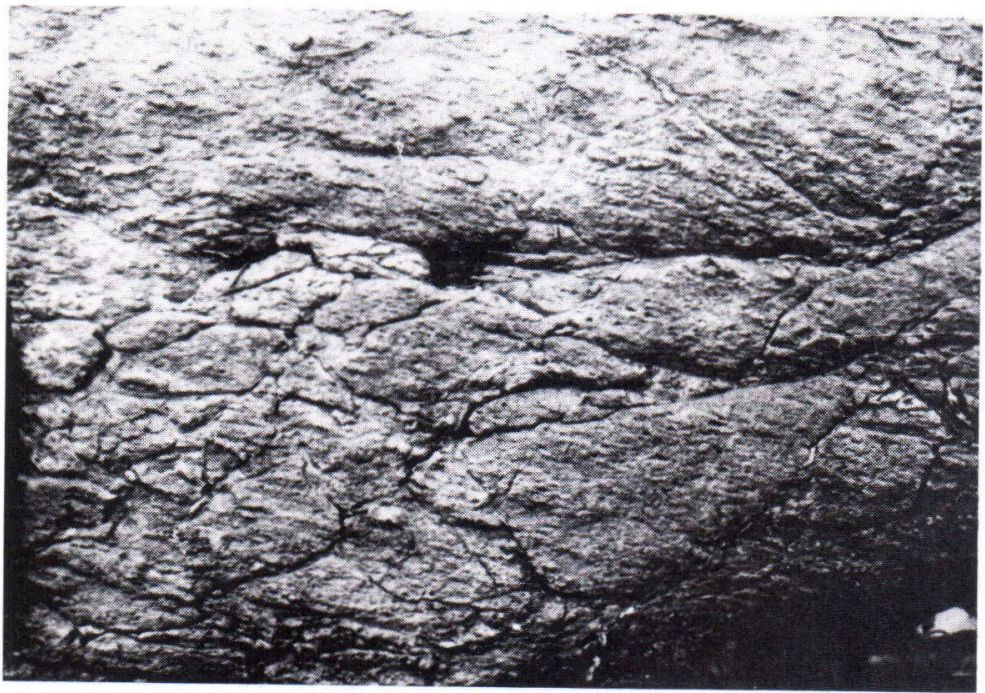

Fig. 7. A typical flow breccia in a fragmental zone of the lava flow. Northernmost part of the Kummitsoiva komatiite complex. The pencil is $14 \mathrm{~cm}$ long. Photo by T. Manninen. actinolite are ellipsoidal and dark green. The carbonaceous amygdules are abundant in the scorias that sometimes appear among the lavas on Kummitsoiva.

The massive or oriented lavas at the margin of the flows grade into fragmentary rocks; between the lava flows they constitute blocky parts $1-5 \mathrm{~m}$ thick. In addition to flow breccias (Fig. 7), the autobrecciated lavas are block lavas composed of fragments $(\emptyset<50$ $\mathrm{cm}$ ) with sharp boundaries and smooth, curved surfaces. Spherical fragments occur frequently, but angular fragments rarely. The fragments touch one another, and some of their long, joined edges are chloritized as if welded together. The interstices, rarely filled with younger lavas (Fig. 8), usually appear as pyroclastic accumulations. As the amount of pyroclastic debris increases, block lavas grade into coarse-grained pyroclastic rocks.

Pillow structures are very rare, but one pillow lava observed together with block

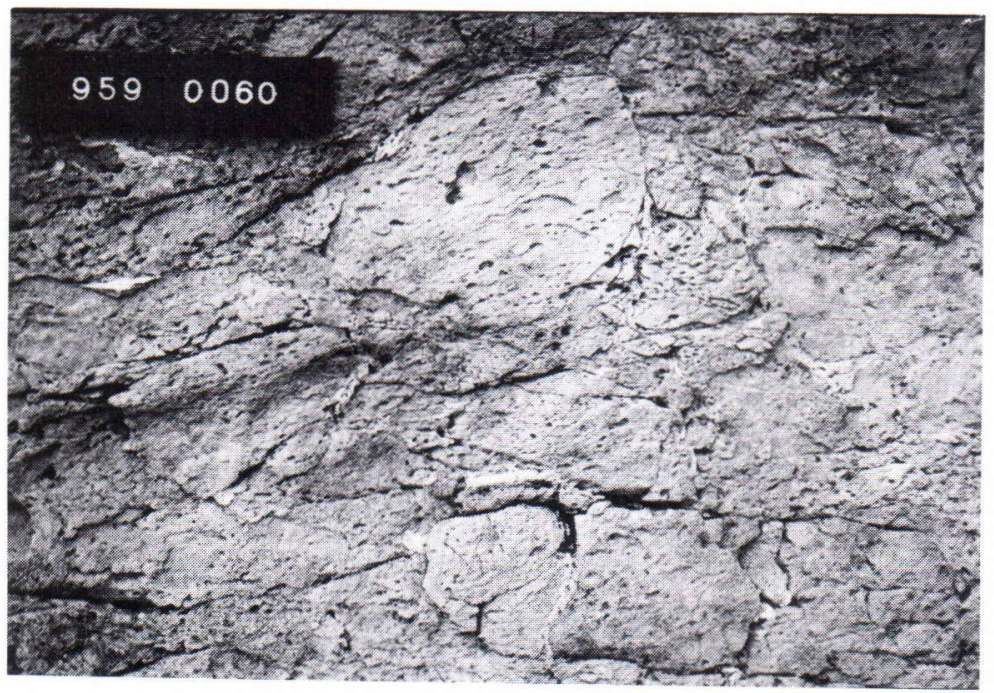

Fig. 8. Block lava with interstices between the blocks filled with younger lava. Amygdules are visible as round and elliptical, dissolved pits on the weathering surface. Lighter veinlets lining the blocks are cracks filled with tremolite. About $4 \mathrm{~km}$ northeast of Kummitsoiva. The index plate is $16 \mathrm{~cm}$ long. Photo by the author. 
Fig. 9. An isolated lava pillow in a chlorite-rich matrix, with a fluidal-shaped flow breccia as its core. The lava was probably still fluidal when it erupted into water to form pillows around soft fragments of autobrecciated margins of the lava flow. The outcrop lies about $30 \mathrm{~m}$ from the block lava in Figure 8, and about $4 \mathrm{~km}$ northeast of Kummitsoiva. The index plate is $16 \mathrm{~cm}$ long. Photo by the author.

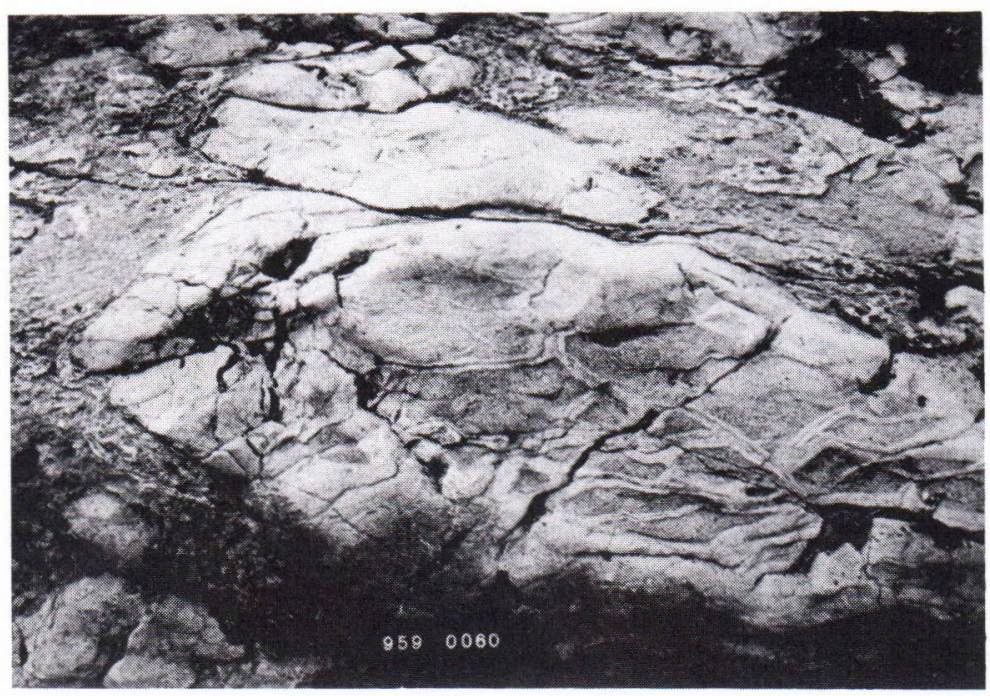

lavas showed isolated pillows with flowtextured flow breccia as their cores (Fig. 9). There are also some pillow breccias in the tuffitic matrix (Räsänen 1983).

The lavas in the lower part of the complex contain irregular, lenticular inclusions of skarn-like schist, graphitic slate and dolomite. The volcanic neck at Känespella has blocks of Salla greenstone in its volcanic breccia.

The lavas contain appreciable amphibole, chlorite and minor amounts of calcite aggregates. Magnetite is disseminated or occurs as scattered grains. A few olivine xenoblasts and idiomorphic pyrite crystals exist as well.

Narrow, intersecting joints filled with tremolite form well-defined primary structures, occasionally lining the blocks. In the massive rocks, the tremolite veinlets display rare polygonal jointing.

\section{Coarse-grained pyroclastic rocks}

The coarse-grained pyroclastic rocks are agglomerates, pyroclastic breccias and lapillistones. They have a greenish grey fresh surface and a brownish or greenish weathering surface. Poorly sorted, loosely packed and crudely stratified (Fig. 10), they include fine-grained pyroclastic parts with transitional boundaries. Sparse cinderites have been encountered (Fig. 11). One agglomerate on Kummitsoiva is an exceptional rock in that its well-rounded pyroclasts appear to be reworked (Fig. 12).

The pyroclasts, generally lapilli and small bombs, are rounded or subrounded, although some angular fragments also exist. The lapilli may be drop-shaped or fusiform, and some of the largest pyroclasts display spatter-like features.

Coarse-grained ejecta are visible on the weathering surface of the rocks as lightercoloured and more resistant rocks than the surrounding tuffaceous matrix. In the more foliated, generally tuff-rich rocks, however, they are ghost-like and foliated. The pyroclasts range from very fine-grained to medium-grained, and some also exhibit a finergrained margin around a core of older lava (Fig. 13). Like the lavas, the bombs and lapilli are massive or oriented, but they may be scoriaceous too. 


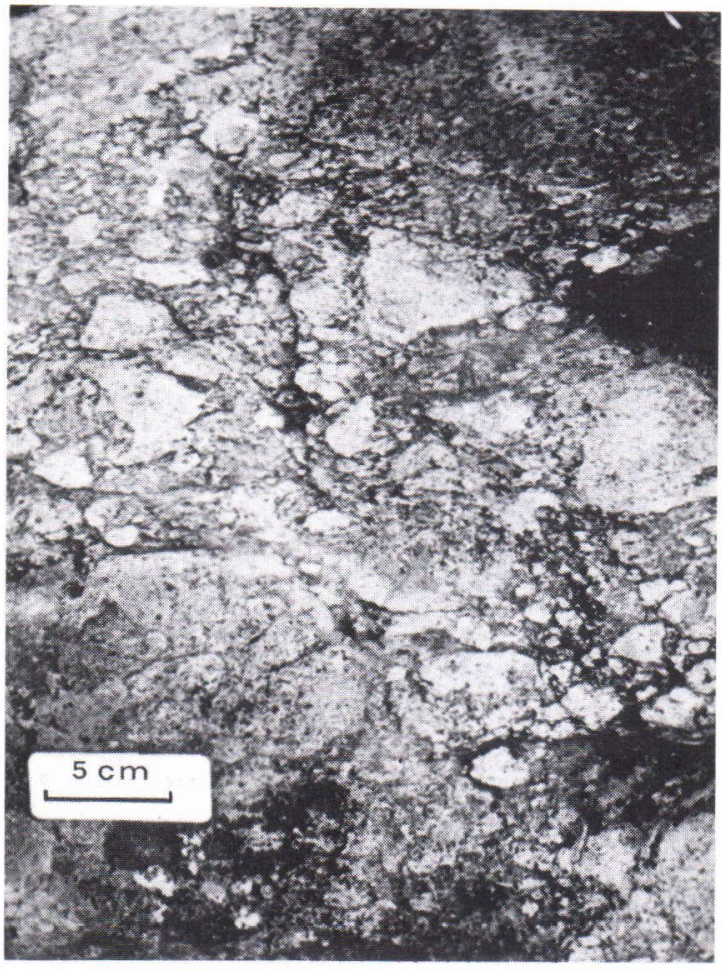

Fig. 10. Lapillistone containing rounded bombs may be the most common type of coarse-grained pyroclastic rock. About $3 \mathrm{~km}$ northwest of Kummitsoiva. Photo by the author.
Both the essential and the accessory ejecta consist primarily of amphibole-chlorite pyroclasts and contain scattered lava drops with rusty surfaces and graphite and magnetiterich lapilli. The accidental ejecta consist of graphite-bearing clasts, carbonaceous lumps and, in the satellitic komatiite at Tuohivaara, cobbles of Salla greenstone.

The tuffaceous matrix contains appreciable amphibole and chlorite and is similar to the fine-grained pyroclastic rocks into which the coarse-grained pyroclastic rocks grade when the amount of matrix increases.

Tremolite veins cut the agglomerates and pyroclastic breccias and, in places, they line pyroclasts. Some of the veins include asbestos veinlets and magnetite aggregates.

\section{Fine-grained pyroclastic rocks}

The fine-grained pyroclastic rocks range from lapilli tuffs to tuffs and contain megascopically unidentifiable epiclastic volcanic siltstone with sandy parts. They all have a green grey fresh surface and a brownish or green grey weathering surface. The tuffs were originally composed of fine-grained and

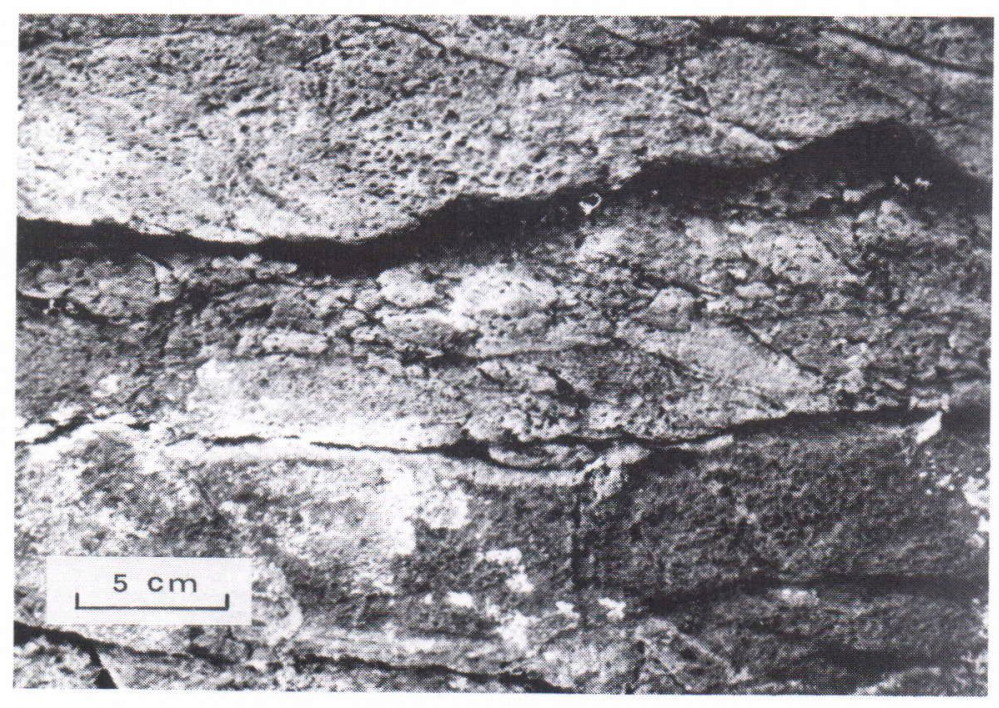

Fig. 11. A pyroclastic accumulation composed of cinders deposited in an essentially solid state. Some contacts appear to be welded. The vesicularity of the ejecta is apparent on a weathering surface covered with small pits. About $3 \mathrm{~km}$ northwest of Kummitsoiva. Photo by the author. 
Fig. 12. A pyroclastic rock with well-rounded and disorderly packed lapilli and bombs. Apparently redeposited. The eastern lower slope of Kummitsoiva. The index plate is $16 \mathrm{~cm}$ long. Photo by the author.

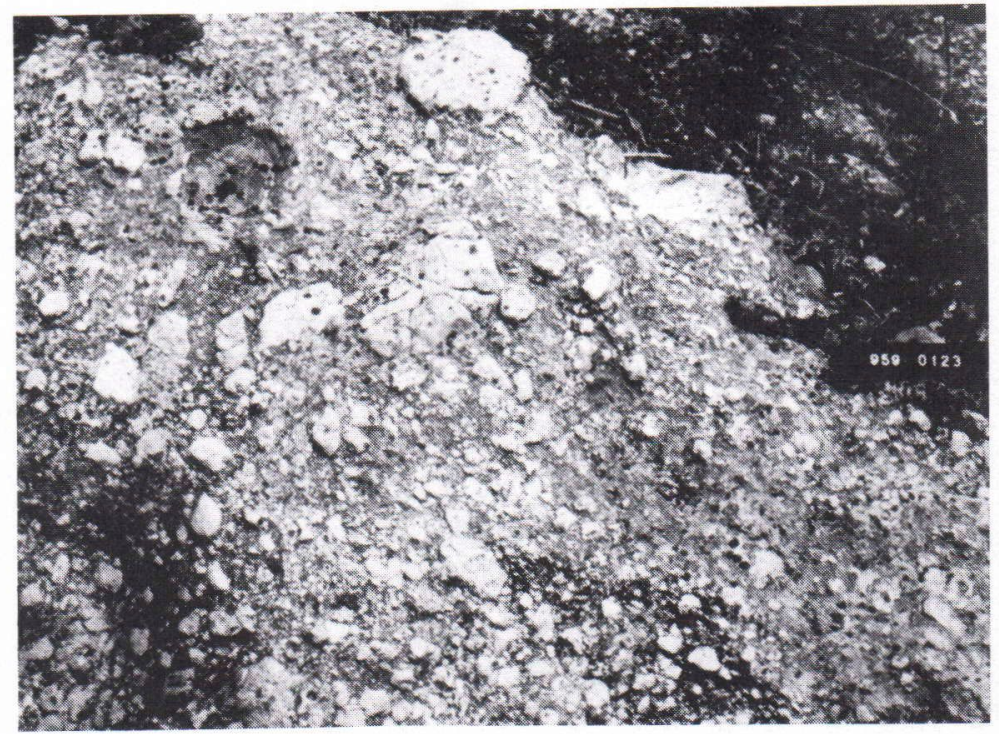

coarse-grained ash, and their lapilli and bombs occur sporadically or as crude accumulations.

The slightly foliated tuffs and lapilli tuffs are compact or consist of massive beds of coarse-grained tuff and foliated beds of finegrained tuff. The rocks are most strongly deformed and, in places, tightly folded in the lowermost part of the exposures.
Sometimes the beds of fine-grained tuff are laminated and sharp-edged. They range in thickness from 0.1 to $5 \mathrm{~cm}$, but beds $5-15 \mathrm{~cm}$ thick are not uncommon. The bedding planes are nearly planar or undulatory and form ripple marks. Small-scale, gentle crossbedding has been encountered but scourand-fill structures are rare. Some of the beds and laminae contain graded graphite, but the
Fig. 13. A pyroclastic breccia composed of tightly packed lapilli and bombs, one of which has a fragment of an older solidified lava at its core. About $9 \mathrm{~km}$ east of Kummitsoiva. The pencil is $14 \mathrm{~cm}$ long. Photo by T. Manninen.

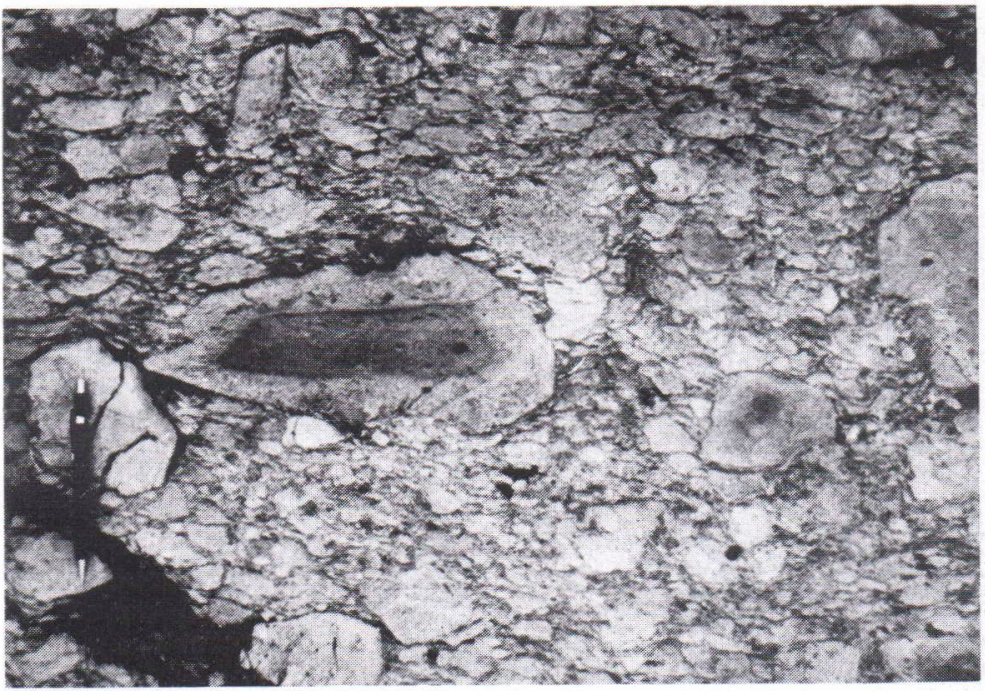


thickest beds include graphite-bearing intraclasts $(\emptyset 0.1-1 \mathrm{~cm})$.

The beds of coarse-grained tuff, $10-70 \mathrm{~cm}$ thick, are massive or graded, and their boundaries are not always sharp. They contain a few graphitic clasts in addition to wellrounded pebbles and cobbles of amygdaloidal amphibole-chlorite rock and angular quartz granules and pebbles.

The tuffs are amphibole-chlorite slates with disseminated carbonate and magnetite. The accessory sulphide minerals are pyrite, chalcopyrite and pyrrhotite. Olivine xenoblasts $(\emptyset 1-3 \mathrm{~cm})$ are common in the marginal zones of the fine-grained pyroclastic rocks in contact with granites. The tuffs in the lower part of the complex contain aggregates of cummingtonite needles.

The tuff-rich rocks have interbeds of graphitic slate, phyllite, mica schist and andesitic tuff. They are usually laminated and $0.5-100$ $\mathrm{cm}$ thick, but the thickest graphitic slate interbed observed in a diamond drill core is $16 \mathrm{~m}$. The graphitic strata appear as electric conductors some $\mathrm{km}$ long.

The dark grey or black graphitic slates, which are rarely rich in graphite, include sulphide and chert laminae. The grey phyllite includes sulphide laminae, but amphibole needles and andalusite idioblasts also occur.
The greyish mica schist contains heterogeneous amphibole bands, pyrrhotite laminae and skarn-like lumps. The andesitic tuff is a dark green, fine-grained and laminated slate, and in places the laminae form small-scale, gentle cross-bedding.

The fine-grained pyroclastic rocks and their interbeds, particularly the graphitic slates, at the bottom of the exposures are slumped and often form folds, gliding surfaces (Fig. 14) and glide breccias with intraclasts of fine-grained and coarse-grained tuff and graphitic slate. The largest slump-bedding zone exposed is 5-7 $\mathrm{m}$ thick and has been observed on the eastern lower slope of Kummitsoiva.

\section{Microscopic textures}

Many rocks are so thoroughly recrystallized that the primary textures are not always microscopically visible. The less recrystallized medium-grained amphibole-chlorite rocks in the lower parts of the lavas seem to be cumulates, but the fine-grained upper parts of the lavas are massive and mineralogically homogeneous. The marginal zones of the lava flows are microcrystalline, and their brecciated parts are welded. The fine-grained, microscopically fragmentary massive rocks

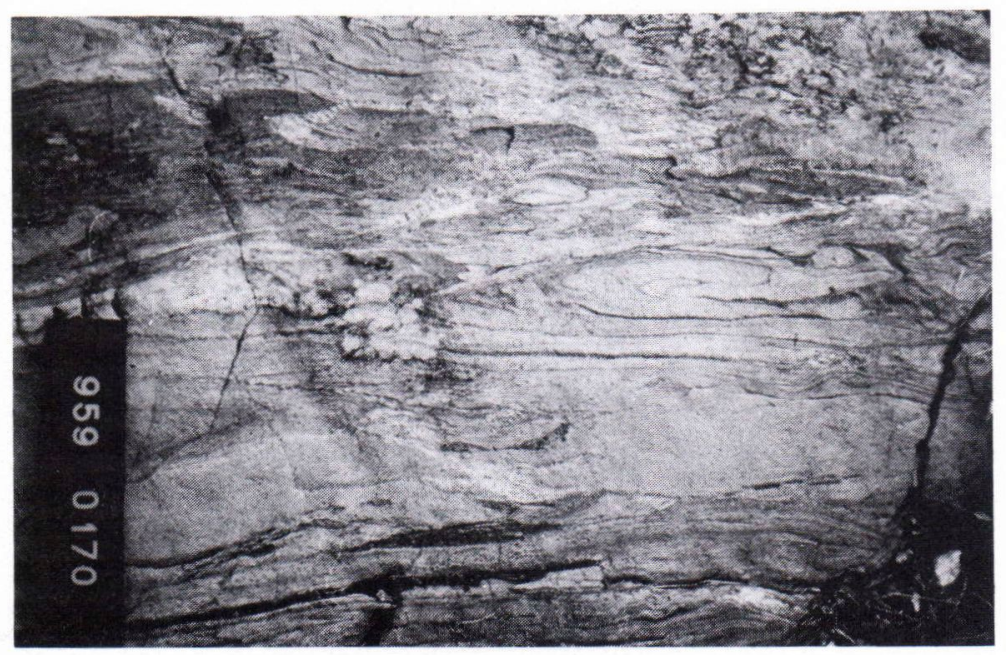

Fig. 14. Pointing towards the upper right-hand corner of the photograph are slump folds and gliding surfaces in a graphitebearing komatiitic tuff. About $7 \mathrm{~km}$ east of Kummitsoiva. The index plate is $16 \mathrm{~cm}$ long. Photo by the author. 
appear to be an ancient weathering crust of the lava flows.

The pyroclasts are lithic and vitric, and the rocks they constitute differ from one another mainly in the size of the ejecta. The epiclastic volcanic siltstones with sandy parts display a polymictic clastic texture.

The serpentine-olivine rocks are cumulates and lithic-crystal tuffs and are associated with an epiclastic rock containing serpentine clasts.

The lavas, $0.05-0.2 \mathrm{~mm}$ in grain size, are usually nematoblastic and massive. They contain appreciable amphibole, chlorite and minor, anhedral opaque minerals. The amphibole needles consist of tremolite and actinolite with weak pleochroism.

Phenocrysts $(\varnothing \quad 0.3-2 \mathrm{~mm}$ ) appear in the amphibole-chlorite cumulates as uralitized tremolite-actinolite and as relicts formed by opaque mineral dust in aggregates of the tremolite laths. The phenocrysts have crystal faces, but intercumulus and drop-like habits also exist. The euhedral relicts are prismatic, dipyramidal and hexagonal, and the opaque mineral dust-free striae delineate an original pyroxene cleavage. Augite twinning is preserved in uralitic crystals. The phenocrysts contain chloritized cumulative nodules $(\varnothing$ 0.2-0.7 $\mathrm{mm}$ ) with sharp contacts. The nodules in the amphibole-chlorite groundmass are aggregates of chlorite patches surrounded by randomly oriented tremolite needles.

The predominant mineral in the microcrystalline marginal zones of the lavas is acicular colourless amphibole. The cryptocrystalline chlorite occurs as two distinct phases: as dissemination in an amphibole groundmass, and as devitrified droplets with fluidal shapes. The spherical droplets have spherulitic amphibole rims. The fragments in the brecciated margin of the lavas have sharp boundaries and are corroded (Fig. 15). The welded matrix contains abundant cryptocrystalline chlorite and acicular amphibole that form

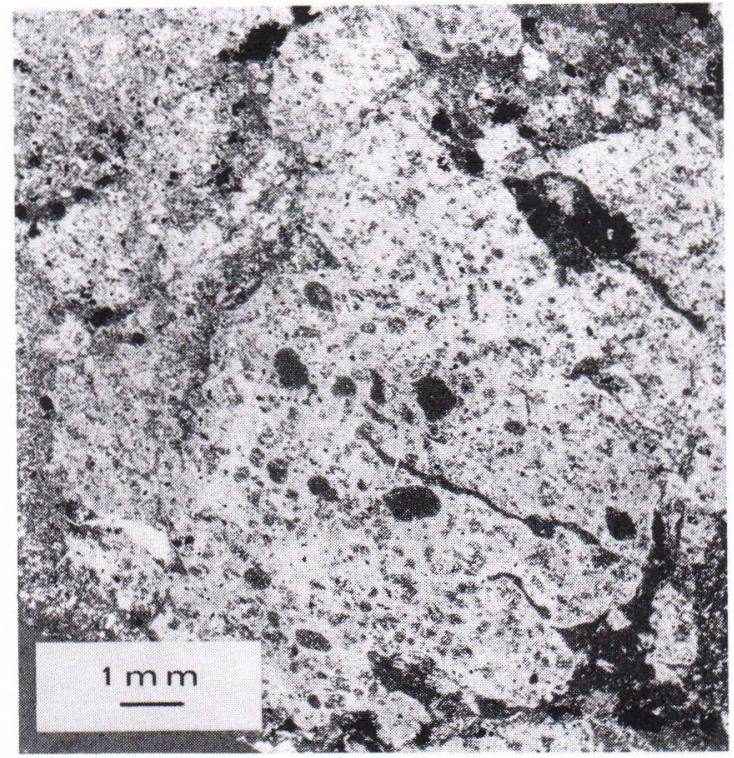

Fig. 15. Fragmentary lava with devitrified droplets and long, narrow fluidal-shaped joints filled with devitrified volcanic glass. In the photograph, cryptocrystalline chlorite is dark grey, and acicular amphibole is greyish. Crossed polars. The southeastern lower slope of Kummitsoiva. Photo by E. Halme.

sharply outlined monomineralic droplets and nodules.

The rocks regarded as an ancient weathering crust contain loosely packed fragments of greenish cryptocrystalline chlorite (Fig. 16). The nematoblastic matrix is composed of turbid tremolite and chlorite. Opaque minerals, mostly lining the clasts, are also present.

In contrast to the reworked lithic ejecta (Fig. 17), the coarse-grained pyroclasts, which are lithologically similar to the microcrystalline lavas, do not always have sharp outlines. The matrix $(\varnothing \quad 0.01-0.2 \mathrm{~mm})$ around them consists of randomly oriented tremolite needles and chlorite patches, but the reworked matrix is slightly oriented.

The fine-grained pyroclasts are lithic and devitrified, but some crystals also exist. The lithic pyroclasts are similar to microcrystal- 


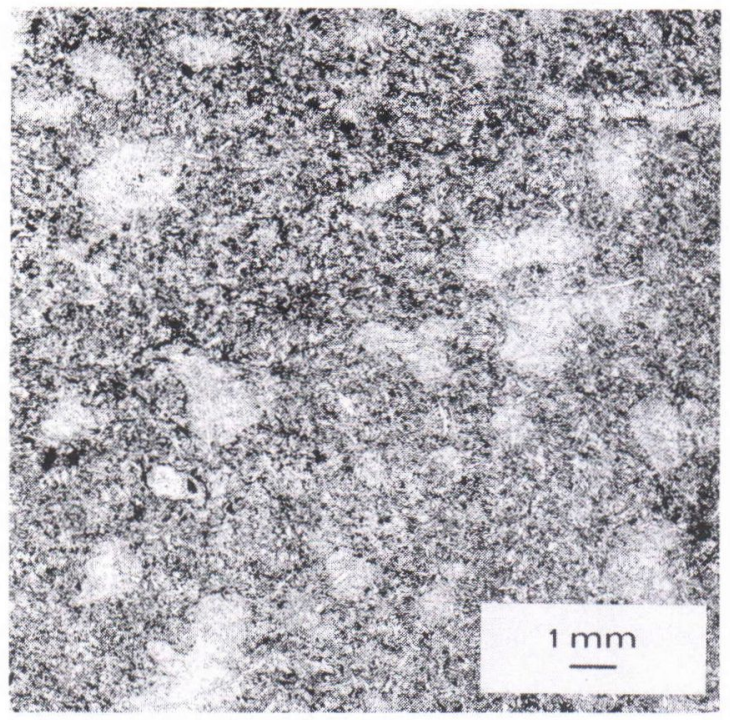

Fig. 16. Ghost-like clastic features in the rock regarded as an ancient weathering crust of the lava flow. Lighter-coloured chlorite-rich fragments in turbid matrix composed of tremolite needles, chlorite and opaque minerals. Plane-polarized light transmitted. About $5 \mathrm{~km}$ northeast of Kummitsoiva. Photo by E. Halme.

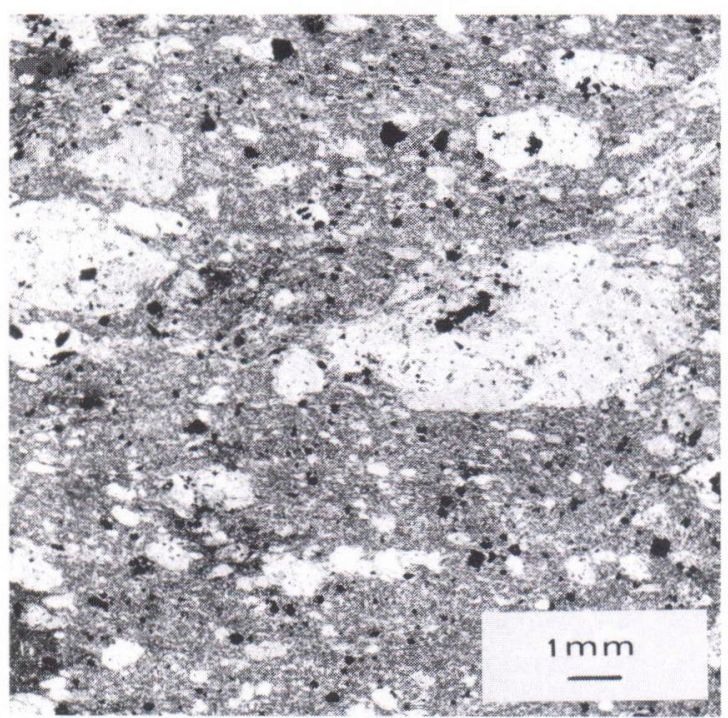

Fig. 17. Lithic lapilli and coarse ash particles in slightly oriented tremolite-chlorite matrix with some opaque minerals. Crossed polars. Photo by E. Halme. Megascopic textures shown in Figure 12.

The eastern lower slope of Kummitsoiva.

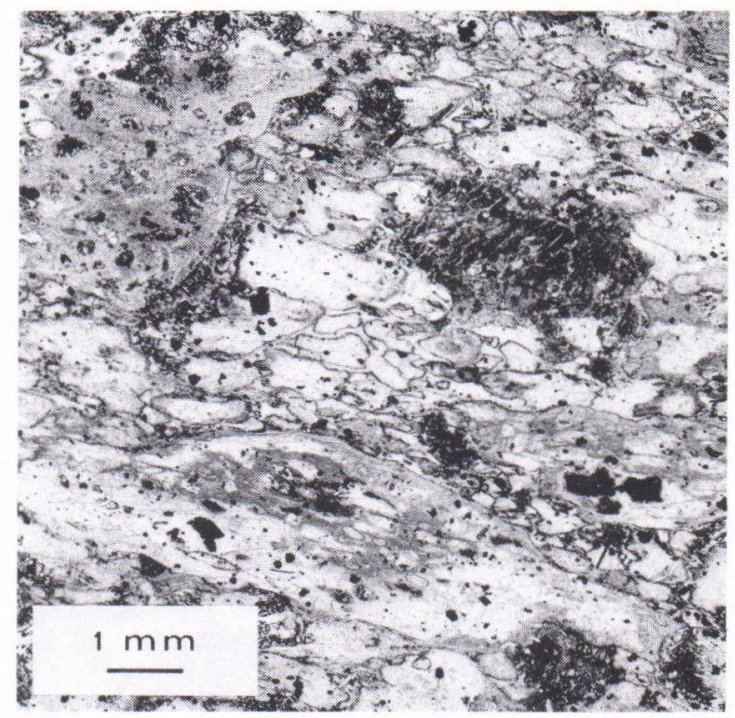

Fig. 18. Lapilli tuff composed mainly of vitric coarse ash and lithic lapilli. In the photograph, vitric pyroclasts and the matrix, as cryptocrystalline chlorite, are colourless, and amphibole-rich lithic material is greyish. Some olivine crystals are also visible. Skins of the vitric clasts have altered into acicular amphibole. Plane-polarized light transmitted. The northernmost part of the Kummitsoiva komatiite complex. Photo by E. Halme.

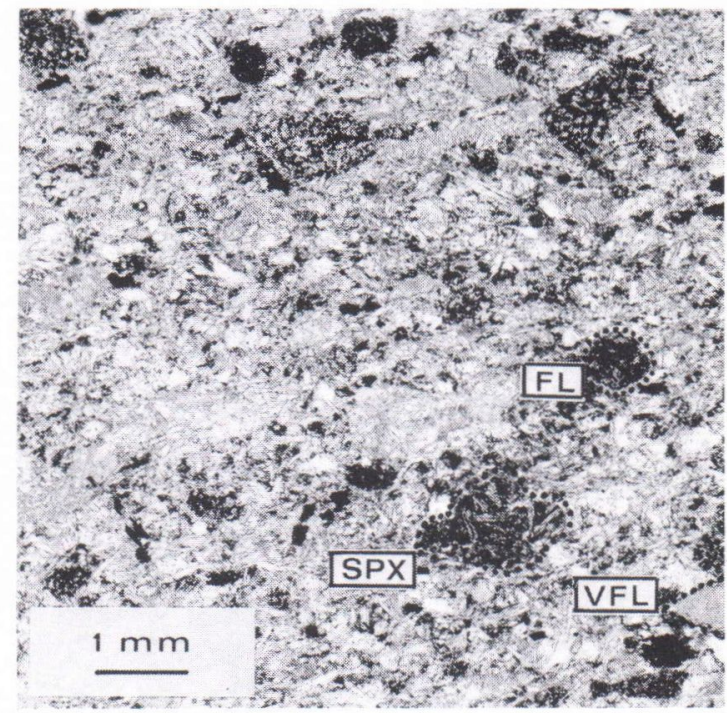

Fig. 19. Volcanic sandstone with epiclastic texture. Epiclasts are very fine-grained lava (VFL), fine-grained lava (FL) and spinifex-textured lava (SPX). Plane-polarized light transmitted. About $3 \mathrm{~km}$ east of Kummitsoiva. Photo by E. Halme. 
line lavas with devitrified droplets in a cryptocrystalline amphibole-chlorite groundmass. Fluidal-shaped pyroclasts with flow textures made up of narrow stripes of chlorite and amphibole occur together with the subangular and subrounded ejecta. The devitrified pyroclasts $(\varnothing 0.02-5 \mathrm{~mm})$ are mostly fluidal and drop-shaped (Fig. 18), but a few of the cryptocrystalline chlorite clasts occur as shards.

Crystal ejecta are associated with vitric ejecta. The crystals are granular olivine and pyroxene, and do not always have definite crystal habits.

The matrix around the fine-grained pyroclasts is partly vitric, and contains acicular amphibole and opaque minerals in addition to cryptocrystalline chlorite.

The clasts in the epiclastic volcanic siltstone with sandy parts originate from marginal zones of lavas or from pyroclasts. They are rounded or well-rounded grains of amphibole rocks, chlorite rocks and amphibole-chlorite rocks. Excluding the clasts composed of tremolite laths, their grains normally range from cryptocrystalline to $0.05 \mathrm{~mm}$ in diameter. One of the clasts observed has a spinifex texture with orthopyroxene prisms in a fibrolitic groundmass (Fig. 19). The clasts $(\varnothing 0.01-2$ $\mathrm{mm}$ ) appear to be tightly packed in a turbid nematoblastic matrix consisting of tremolite needles and chlorite. The matrix also contains opaque minerals and feldspar or quartz as accessory minerals.

The serpentine-olivine cumulates consist mainly of nodules altered into monomineralic aggregates of serpentine and tremolite. Bastite forms pseudomorphic phenocrysts $(\varnothing 0.5-$ $3 \mathrm{~mm}$ ) with corroded crystal faces and nodular serpentine-tremolite-chlorite inclusions. The olivine phenocrysts $(\varnothing 1-6 \mathrm{~mm})$ are also euhedral, and their margins are altered into iddingsite. Chlorite forms a few intercumulus aggregates. Because bastite is an alteration product of orthopyroxenes (Tröger

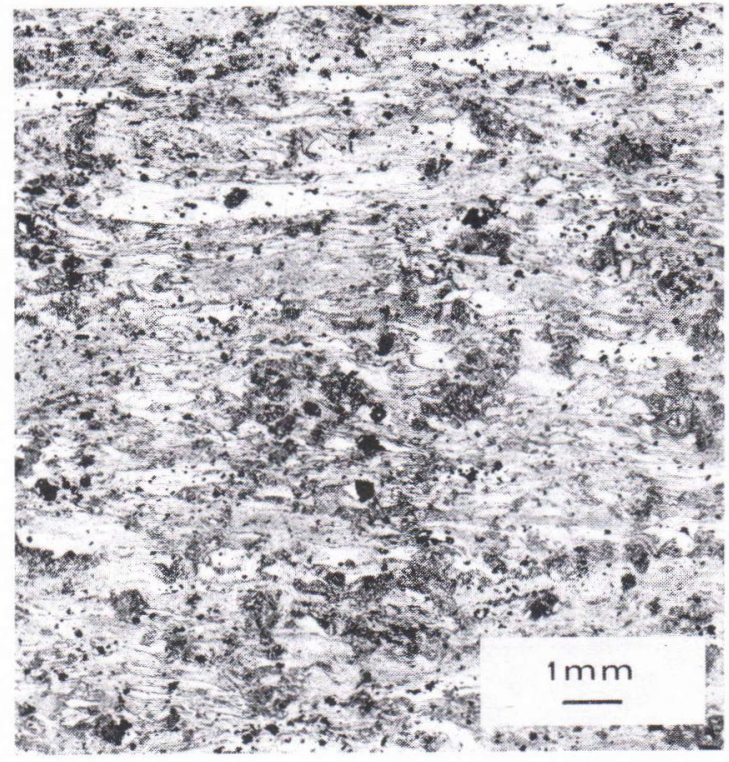

Fig. 20. Pyroclastic olivine-pyroxene rock with appreciable crystal and lithic ejecta. In the photograph, crystals, mainly olivine, are grey and lithic material is greyish, but vitric ejecta are colourless. The rock was originally lapilli-bearing, coarsegrained lithic-crystal tuff. Plane-polarized light transmitted. The northernmost part of the Kummitsoiva komatiite complex. Photo by E. Halme.

1967), the rock was originally an olivine-pyroxene cumulate.

As lithic-crystal tuffs, the pyroclastic olivine-pyroxene rocks contain fluidal and drop-shaped ash particles and fine-grained lapilli devitrified into cryptocrystalline chlorite (Fig. 20). The skin of the pyroclasts has often been converted into acicular amphibole. The matrix also contains tremolite needle-bearing parts with a fluidal texture. Olivine and clinopyroxene form granular crystals and nodular aggregates $(\emptyset 0.1-3 \mathrm{~mm})$

The clasts in the epiclastic serpentine rock may be derived from olivine-pyroxene cumulates. They consist of serpentine and have cracks filled with chlorite. The clasts $(\varnothing 0.05-$ $3 \mathrm{~mm}$ ) are rounded and appear to be tightly packed although the smallest ones are mixed in a tremolite-chlorite matrix (Fig. 21). 


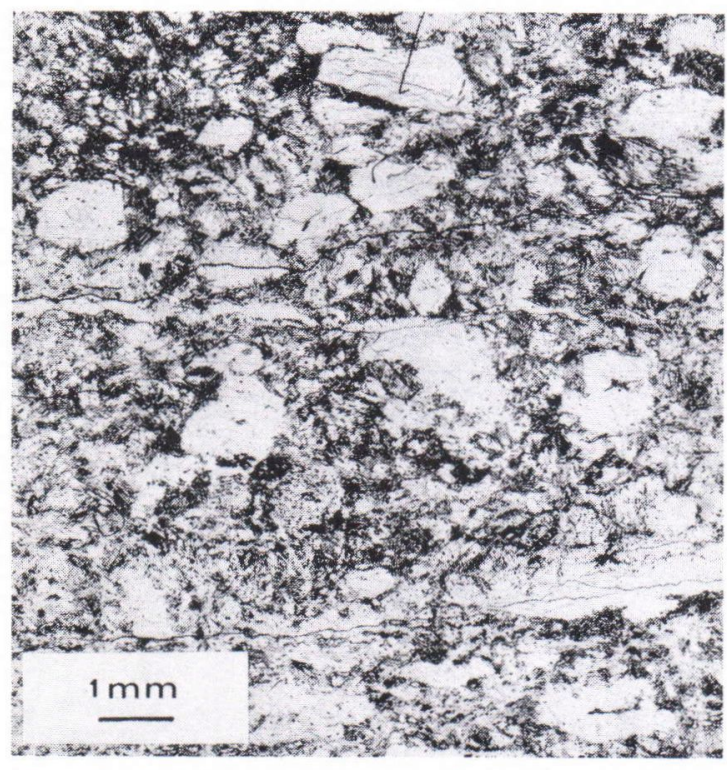

Fig. 21. Epiclastic texture in the serpentine rock containing serpentine clasts in a matrix composed of tremolite needles and chlorite. Plane-polarized light transmitted. About $7 \mathrm{~km}$ northwest of Kummitsoiva. Photo by E. Halme.

Primary olivine can often be distinguished from secondary olivine, which forms ragged, anhedral porphyroblasts with margins altered into iddingsite and bowlingite. The cleavage planes are serpentinized and contain disseminated opaque minerals. Some of the porphyroblasts exhibit features of crystal faces, proving that they may be, at least partly, overgrowths of primary olivine crystals.

The recrystallization of the rocks described above is manifested by secondary minerals, particularly tremolite and chlorite. Colourless acicular amphibole alters into tremolite needles before it forms laths. Cryptocrystalline chlorite grows into patches. As the rate of recrystallization increases, more tremolite laths are added, which then form randomly oriented aggregates, whereas the chlorite patches accumulate on foliation planes. Thus, the primary textures are ghost-like and the chlorite aggregares, for instance, are recrys- tallized to such an extent that it is not possible to tell whether they were originally cumulative nodules, volcanic glassy droplets or vitric ejecta.

\section{Geochemical features}

The samples were analysed by XRF. The classification used is that suggested by Arndt and Brooks (1980) in which basaltic komatiites are distinguished from other komatiites, albeit by an undefined chemical limit. In this way the distinct mineralogical and petrographical differences between the basaltic komatiites, or amphibole-chlorite rocks, and the numerous komatiites outside the Kummitsoiva area, previously regarded as peridotites and serpentinites, are emphasized. Arndt and Nisbet (1982) do not attempt to distinguish these rocks.

Chemically, the amphibole-chlorite rocks, the lavas and the pyroclastic rocks differ little from one another (Tables 1-3). The only marked differences seem to be the depleted $\mathrm{SiO}_{2}$ content and the enhanced $\mathrm{MgO}$ content in the fine-grained pyroclastic rocks (Table 3), possibly due to the presence of crystal ejecta. With the exception of a cumulate, they are all basaltic komatiites with $\mathrm{MgO}$ content between 20.15 and 25.41 wt.\% and grading from ultramafic to mafic $\left(\mathrm{SiO}_{2} 39.42-49.52 \mathrm{wt} \%\right)$. On the $\mathrm{CaO}-\mathrm{MgO}-\mathrm{Al}_{2} \mathrm{O}_{3}$ and $\mathrm{Al}_{2} \mathrm{O}_{3}-\mathrm{FeO}+$ $\mathrm{Fe}_{2} \mathrm{O}_{3}+\mathrm{TiO}_{2}-\mathrm{MgO}$ diagrams (Fig. 22) they correspond to the Geluk-type of basaltic komatiites in South Africa (Viljoen et al. 1982).

The epiclastic volcanic siltstones with sandy parts differ chemically from the other amphibole-chlorite rocks, being depleted in MgO but enriched in $\mathrm{SiO}_{2}, \mathrm{Al}_{2} \mathrm{O}_{3}$ and $\mathrm{TiO}_{2}$ (Table 3, Fig. 23). The chemical variations are due to dissolution during weathering and transportation. But the chemical composition of the ancient weathering crusts compared with the average composition of the lavas (Table 1) is no proof that the weathering was 
Table 1. XRF analyses of amphibole-chlorite rocks, originally massive lava flows in the Kummitsoiva komatiite complex. Analysed by Väinö Hoffrén of the Geological Survey of Finland, Espoo.

\begin{tabular}{lrrrrrrrrrrrr}
\hline wt. \% & \multicolumn{1}{c}{2} & \multicolumn{1}{c}{2} & \multicolumn{1}{c}{3} & \multicolumn{1}{c}{4} & \multicolumn{1}{c}{5} & \multicolumn{1}{c}{6} & 7 & 8 & 9 & $\overline{\mathrm{x}}$ & \multicolumn{1}{c}{10} & 11 \\
\hline $\mathrm{SiO}_{2}$ & 41.80 & 42.35 & 42.97 & 43.43 & 41.84 & 42.04 & 44.11 & 45.68 & 42.39 & 42.96 & 41.98 & 43.81 \\
$\mathrm{Al}_{2} \mathrm{O}_{3}$ & 6.46 & 5.72 & 6.41 & 5.17 & 7.71 & 6.48 & 7.35 & 6.44 & 7.94 & 6.63 & 7.28 & 5.95 \\
$\mathrm{Fe}_{2} \mathrm{O}_{3}{ }^{*}$ & 13.03 & 13.68 & 13.26 & 9.69 & 10.19 & 14.84 & 13.52 & 12.17 & 11.05 & 12.38 & 13.52 & 13.02 \\
$\mathrm{MgO}$ & 23.88 & 22.94 & 22.92 & 23.84 & 25.08 & 22.84 & 20.15 & 20.64 & 23.87 & 22.91 & 23.61 & 22.57 \\
$\mathrm{CaO}$ & 5.74 & 6.73 & 6.43 & 7.99 & 5.66 & 6.04 & 7.16 & 7.14 & 6.23 & 6.57 & 6.26 & 7.02 \\
$\mathrm{Na}_{2} \mathrm{O}$ & .54 & 1.13 & .92 & .90 & 1.20 & .60 & 1.44 & .94 & .85 & .95 & .85 & .79 \\
$\mathrm{~K}_{2} \mathrm{O} *$ & .00 & .00 & .00 & .00 & .00 & .00 & .00 & .00 & .00 & .00 & .00 & .00 \\
$\mathrm{MnO}$ & .19 & .21 & .10 & .27 & .18 & .13 & .21 & .25 & .19 & .19 & .15 & .24 \\
$\mathrm{TiO}_{2}$ & .57 & .59 & .66 & .45 & .46 & .73 & .60 & .61 & .56 & .58 & .58 & .70 \\
$\mathrm{P}_{2} \mathrm{O}_{5}$ & .04 & .05 & .04 & .04 & .04 & .03 & .00 & .00 & .05 & .03 & .04 & .05 \\
$\mathrm{H}_{2} \mathrm{O}$ & - & - & - & 6.02 & - & - & - & - & - & - & - & - \\
$\mathrm{CO}_{2}$ & - & - & - & 2.30 & - & - & - & - & - & - & - & - \\
\hline $\mathrm{Total}$ & 92.25 & 93.40 & 93.71 & 100.10 & 92.36 & 93.73 & 94.54 & 93.87 & 93.13 & & 94.27 & 94.15 \\
\hline $\mathrm{CaO}_{2} \mathrm{Al}_{2} \mathrm{O}_{3}$ & .89 & 1.18 & 1.00 & 1.55 & .73 & .93 & .97 & 1.11 & .78 & & .86 & 1.18 \\
$\mathrm{Al}_{2} \mathrm{O}_{3} / \mathrm{TiO}_{2}$ & 11.33 & 9.69 & 9.71 & 11.49 & 16.76 & 8.88 & 12.25 & 10.56 & 14.18 & & 12.55 & 8.50 \\
\hline
\end{tabular}

- not determined

* total $\mathrm{Fe}$ as $\mathrm{Fe}_{2} \mathrm{O}_{3}$

** detection limit for $\mathrm{K}_{2} \mathrm{O}$ is 0.1 wt. $\%$

\section{Samples:}

1. Cumulate lava containing relict phenocrysts formed by opaque mineral dust, coordinates: $\mathrm{x}=7454.68, \mathrm{y}=543.14$.

2. Cumulate lava containing relict phenocrysts formed by opaque mineral dust, coordinates: $\mathrm{x}=7453.65, \mathrm{y}=543.25$.

3. Cumulate lava containing uralitic tremoliteactinolite phenocrysts, coordinates: $\mathrm{x}=7451.94$, $\mathrm{y}=544.82$.

4. Cumulate lava containing aggregates of tremolite laths, coordinates: $\mathrm{x}=7453.23, \mathrm{y}=540.51$.

5. Autobrecciated lava composed of lithic frag-

as effective an agent as transportation and contemporaneous dissolution.

From only one chemical analysis, one might conclude that the serpentine-olivine rocks, which were originally olivine-pyroxene lavas, are komatiites proper with a higher $\mathrm{MgO}$ content than that of the amphibolechlorite rocks (Table 4). But the pyroclastic olivine-pyroxene rocks overlap the basaltic komatiites, both lavas and pyroclastic rocks, chemically. This overlap and the accumulative amphibole-chlorite rock belonging to the ments welded together, coordinates: $\mathrm{x}=7451.48$, $\mathrm{y}=542.83$.

6. Massive lava containing a few amygdules filled with tremolite, coordinates: $\mathrm{x}=7448.80$, $\mathrm{y}=539.48$.

7. Massive lava containing a few amygdules filled with tremolite-actinolite, coordinates: $\mathrm{x}=7449.02$, $\mathrm{y}=543.46$.

8. Lava containing blebs of cummingtonite and calcite, coordinates: $\mathrm{x}=7446.70, \mathrm{y}=535.78$.

9. Lava containing blebs of cummingtonite and calcite, coordinates: $\mathrm{x}=7441.62, \mathrm{y}=542.56$.

$\overline{\mathrm{x}}$ Average composition of the lavas.

10. Ancient weathering crust containing chloritic fragments (in Figure 16), coordinates: $\mathrm{x}=$ $7451.20, \mathrm{y}=547.14$

11. Ancient weathering crust containing chloritic fragments, coordinates: $\mathrm{x}=7449.00, \mathrm{y}=542.14$.

komatiites (Fig. 22) seem to substantiate the opinion of Viljoen et al. (1982) that the basaltic komatiites of Geluk type should preferably be grouped with komatiites than with komatiitic basalts. However, a gravitational differentiation is reflected in the chemical composition of the accumulative amphibolechlorite rock. The fluidal komatiite lava (see p. 132) could also have been differentiated in the volcanic conduit immediately before an explosion. However, the position of the pyroclastic olivine-pyroxene rocks 
Table 2. XRF analyses of amphibole-chlorite rocks, originally coarse-grained ejecta in the Kummitsoiva komatiite complex. Analysed by Väinö Hoffrén of the Geological Survey of Finland, Espoo.

\begin{tabular}{lrrrrrrrrrrrr}
\hline wt. \% & 12 & 13 & 14 & 15 & 16 & 17 & 18 & 19 & 20 & 21 & 22 & $\overline{\mathrm{x}}$ \\
\hline $\mathrm{SiO}_{2}$ & 39.88 & 43.87 & 42.39 & 41.54 & 49.52 & 44.02 & 47.50 & 43.81 & 42.49 & 40.28 & 43.49 & 43.53 \\
$\mathrm{Al}_{2} \mathrm{O}_{3}$ & 7.12 & 5.24 & 6.51 & 6.58 & 4.24 & 6.19 & 3.50 & 6.03 & 5.94 & 5.11 & 5.24 & 5.61 \\
$\mathrm{Fe}_{2} \mathrm{O}_{3}{ }^{*}$ & 12.59 & 11.86 & 12.03 & 12.57 & 11.15 & 11.53 & 14.01 & 11.85 & 11.21 & 19.23 & 12.25 & 12.75 \\
$\mathrm{MgO}$ & 23.97 & 22.45 & 24.20 & 23.89 & 21.55 & 22.46 & 20.39 & 23.99 & 24.73 & 21.52 & 22.89 & 22.91 \\
$\mathrm{CaO}$ & 6.89 & 7.10 & 6.57 & 5.55 & 7.57 & 7.63 & 8.70 & 5.65 & 6.62 & 6.18 & 7.05 & 6.86 \\
$\mathrm{Na} \mathrm{O}_{2}$ & .81 & .56 & 1.40 & .68 & .64 & 1.42 & .91 & .73 & .76 & .84 & .79 & .87 \\
$\mathrm{~K}_{2} \mathrm{O}^{* *}$ & .00 & .00 & .00 & .00 & .00 & .00 & .00 & .00 & .00 & .00 & .00 & .00 \\
$\mathrm{MnO}_{\mathrm{TiO}_{2}}$ & .14 & .24 & .21 & .17 & .18 & .19 & .26 & .15 & .23 & .17 & .24 & .20 \\
$\mathrm{P}_{2} \mathrm{O}_{5}$ & .64 & .79 & .48 & .59 & .39 & .51 & .47 & .53 & .45 & .79 & .62 & .57 \\
$\mathrm{Total}$ & .05 & .05 & .00 & .03 & .06 & .05 & .07 & .03 & .00 & .04 & .06 & .04 \\
\hline $\mathrm{CaO}_{2} \mathrm{Al}_{2} \mathrm{O}_{3}$ & 92.09 & 92.16 & 93.79 & 91.60 & 95.30 & 94.00 & 95.81 & 92.77 & 92.43 & 94.16 & 92.63 & \\
$\mathrm{Al}_{2} \mathrm{O}_{3} / \mathrm{TiO}_{2}$ & 11.12 & 1.35 & 1.01 & .84 & 1.79 & 1.23 & 2.49 & .94 & 1.11 & 1.21 & 1.35 & \\
\hline
\end{tabular}

* total $\mathrm{Fe}$ as $\mathrm{Fe}_{2} \mathrm{O}_{3}$

** detection limit for $\mathrm{K}_{2} \mathrm{O}$ is 0.1 wt. \%

\section{Samples:}

12. Lithic lapillistone, coordinates: $\mathrm{x}=7450.06$, $\mathrm{y}=546.53$.

13. Lithic lapillistone composed of fluidal-shaped and angular ejecta, coordinates: $\mathrm{x}=7449.66$, $\mathrm{y}=535.75$.

14. Lithic lapillistone containing secondary olivine, coordinates: $\mathrm{x}=7459.06, \mathrm{y}=545.63$.

15. Lithic agglomerate containing secondary olivine, coordinates: $\mathrm{x}=7445.56, \mathrm{y}=540.09$.

16. Lithic agglomerate, slightly recrystallized and carbonate-bearing, coordinates: $\mathrm{x}=7450.04$, $\mathrm{y}=540.02$.

in the upper part of the komatiite interlayers implies that they represent the final stage of the eruption of the komatiite lava.

The epiclastic rock with serpentine clasts, probably separated from a komatiite lava, is depleted in $\mathrm{MgO}$ but enriched in $\mathrm{Al}_{2} \mathrm{O}_{3}$ and $\mathrm{TiO}_{2}$ (Table 4).

The $\mathrm{CaO} / \mathrm{Al}_{2} \mathrm{O}_{3}$ and $\mathrm{Al}_{2} \mathrm{O}_{3} / \mathrm{TiO}_{2}$ ratios of the komatiites and the basaltic komatiites in the Kummitsoiva complex are such that they cannot be divided into Al-depleted and Al-undepleted types as suggested by Nesbitt, Sun and Purvis (1979).
17. Lithic lapillistone, recrystallized, coordinates: $\mathrm{x}=7458.88, \mathrm{y}=545.60$.

18. Lithic agglomerate, strongly recrystallized, coordinates: $x=7448.54, y=539.00$.

19. Lithic-vitric agglomerate, carbonate-bearing and containing fluidal-shaped bombs, coordinates: $\mathrm{x}=7449.42, \mathrm{y}=539.52$.

20. Lithic-vitric lapillistone with fluidal-shaped lapilli containing crystal ejecta (in Figure 18), coordinates: $\mathrm{x}=7459.19, \mathrm{y}=547.05$.

21. Lithic-vitric lapillistone, recrystallized and carbonate-bearing, coordinates: $\mathrm{x}=7450.44$, $\mathrm{y}=540.06$.

22. Lithic lapillistone, reworked (in Figure 17), coordinates: $\mathrm{x}=7449.38, \mathrm{y}=544.46$.

$\overline{\mathrm{x}}$ Average composition of the coarse-grained pyroclastic rocks.

\section{Paleovolcanic environment}

An evolutionary stage in the depositional basin immediately before the explosive komatiite volcanism is manifested by the existence of a graphitic slate zone beneath the komatiites. In addition to graphitic slates and skarn-like schists, it contains interlayers of jaspilitic iron ores, sulphide slates, cherts, dolomites, mica schists and metagreywackes. They form a rock suite of the black-shale "restricted basin» association documented by Krumbein and Sloss (1963, p. 506). 


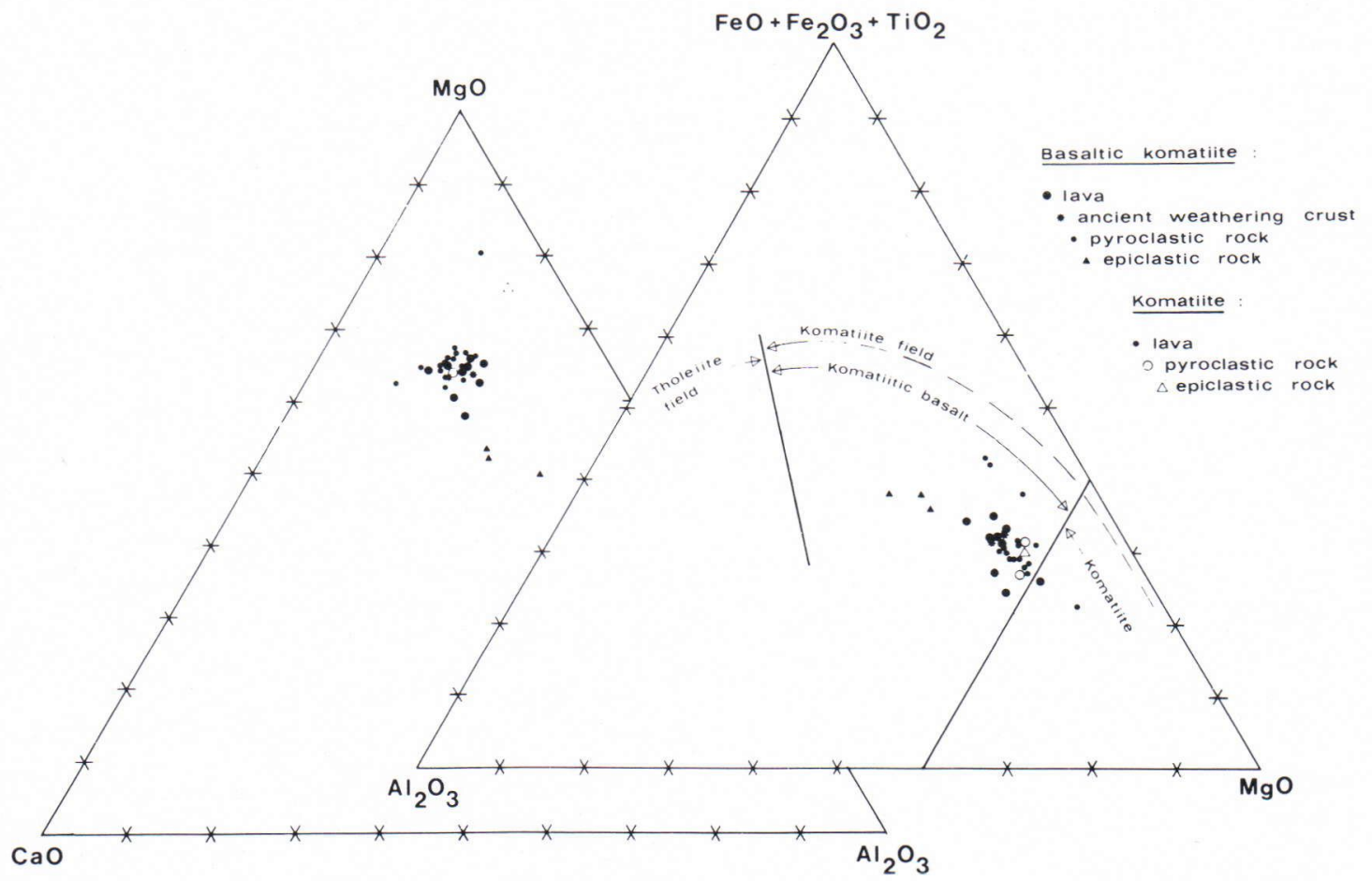

Fig. 22. Chemical composition of komatiites in the Kummitsoiva complex presented on CaO-MgO$\mathrm{Al}_{2} \mathrm{O}_{3}$ and $\mathrm{Al}_{2} \mathrm{O}_{3}-\mathrm{FeO}+\mathrm{Fe}_{2} \mathrm{O}_{3}+\mathrm{TiO}_{2}-\mathrm{MgO}$ diagrams. The boundary between the komatiite and tholeiite fields in the second diagram has been revised after Viljoen et al. (1982).

Komatiite volcanism began during epiclastic and euxinic sedimentation. Nonvolcanic metasediments constitute interlayers at the bottom of the exposed komatiites.

The komatiites emerged mainly through a volcanic conduit $(\emptyset>0.5 \mathrm{~km})$ on present-day Kummitsoiva. The paraconglomerate bordering Kummitsoiva hill beneath the complex may be an apron around the volcanic vent. It consists of local rock fragments $(\emptyset 1-50 \mathrm{~cm})$ and a hornblende-rich matrix. Some lavas erupted through a fissure network which appears as lava dykes $(\varnothing 0.2-150 \mathrm{~m})$ intersecting older supracrustal rocks and the lower part of the Kummitsoiva complex. The formation of fissures required tectonic crushing of the base of the depositional basin. It was most probably caused by faulting coeval with, or immediately preceding, the ultramafic eruptions.

Intertongues of lavas and pyroclastic rocks indicate that the komatiites emerged in various phases. Erosional periods that existed during intervals between the phases produced epiclastic volcanic silt and sand and very crude conglomeratic accumulations. Intermediate volcanism also occurred between the oldest komatiitic phases, when andesitic tuffs were deposited as a few interbeds at the base of the komatiite exposures.

The chemical composition of the erupting ultramafic material, lavas and pyroclasts, was 
Table 3. XRF analyses of amphibole-chlorite rocks, originally fine-grained ejecta and epiclastic debris in the Kummitsoiva komatiite complex. Analysed by Väinö Hoffrén of the Geological Survey of Finland, Espoo.

\begin{tabular}{lrrrrrrrrrr}
\hline wt. \% & 23 & 24 & 25 & 26 & \multicolumn{1}{c}{$\bar{x}$} & 27 & 28 & 29 & $\overline{\bar{x}}$ & 30 \\
\hline $\mathrm{SiO}_{2}$ & 39.42 & 42.07 & 42.66 & 43.30 & 41.86 & 45.75 & 43.76 & 46.66 & 45.39 & 60.37 \\
$\mathrm{Al}_{2} \mathrm{O}_{3}$ & 5.11 & 6.33 & 6.00 & 5.78 & 5.80 & 8.67 & 11.02 & 8.63 & 9.44 & 12.57 \\
$\mathrm{Fe}_{2} \mathrm{O}_{3}{ }^{*}$ & 19.67 & 11.80 & 11.09 & 11.93 & 13.62 & 13.80 & 15.54 & 14.51 & 14.62 & 10.75 \\
$\mathrm{MgO}$ & 22.36 & 24.00 & 25.04 & 25.41 & 24.20 & 17.52 & 15.99 & 16.43 & 16.65 & 6.61 \\
$\mathrm{CaO}$ & 6.28 & 7.57 & 6.43 & 6.63 & 6.73 & 6.78 & 5.20 & 6.74 & 6.24 & 1.89 \\
$\mathrm{Na}_{2} \mathrm{O}$ & .93 & .62 & 1.07 & 1.27 & .97 & 1.38 & 1.80 & 1.81 & 1.66 & 7.06 \\
$\mathrm{~K}_{2} \mathrm{O}^{* *}$ & .00 & .00 & .00 & .00 & .00 & .00 & .00 & .00 & .00 & .00 \\
$\mathrm{MnO}$ & .15 & .16 & .14 & .15 & .15 & .16 & .21 & .16 & .18 & .20 \\
$\mathrm{TiO}_{2}$ & .42 & .51 & .45 & .45 & .46 & .75 & .98 & .81 & .85 & .65 \\
$\mathrm{P}_{2} \mathrm{O}_{5}$ & .00 & .00 & .00 & .00 & .00 & .03 & .00 & .05 & .03 & .06 \\
\hline $\mathrm{Total}$ & 94.34 & 93.06 & 92.88 & 94.92 & & 94.84 & 94.50 & 95.80 & & 100.16 \\
\hline $\mathrm{CaO} / \mathrm{Al}_{2} \mathrm{O}_{3}$ & 1.23 & 1.20 & 1.07 & 1.15 & & .78 & .47 & .78 & & \\
$\mathrm{Al}_{2} \mathrm{O}_{3} / \mathrm{TiO}_{2}$ & 12.17 & 12.41 & 13.33 & 12.84 & & 11.56 & 11.24 & 10.65 & & \\
\hline
\end{tabular}

* total $\mathrm{Fe}$ as $\mathrm{Fe}_{2} \mathrm{O}_{3}$

** detection limit for $\mathrm{K}_{2} \mathrm{O}$ is $0.1 \mathrm{wt} \%$

Samples:

23. Lithic-vitric lapilli tuff composed of fluidalshaped clasts and shards, coordinates: $\mathrm{x}=$ $7459.58, \mathrm{y}=547.00$.

24. Vitric-lithic tuff composed of fluidal-shaped ejecta, coordinates: $\mathrm{x}=7459.54, \mathrm{y}=547.00$.

25. Lithic lapilli tuff with vitric shards, associated with lava flows, coordinates: $\mathrm{x}=7459.50, \mathrm{y}=$ 547.16 .

26. Vitric-lithic tuff composed of vitric droplets and shards and lithic lapilli, coordinates: $\mathrm{x}=$
$7459.35, y=546.34$.

$\overline{\mathrm{x}}$ Average composition of the fine-grained pyroclastic rocks.

27. Epiclastic volcanic sandstone, massive in the outcrop, coordinates: $x=7448.86, y=545.00$.

28. Epiclastic volcanic silty sandstone including graphitic slate interbeds in the outcrop, coordinates: $\mathrm{x}=7447.40, \mathrm{y}=550.22$.

29. Epiclastic volcanic silty sandstone (in Figure 19) including andesitic tuff interbeds in the outcrop, coordinates: $\mathrm{x}=7448.44, \mathrm{y}=545.30$.

$\overline{\mathrm{x}}$ Average composition of the epiclastic rocks.

30. Andesitic tuff, coordinates: $x=7448.36, y=$ 545.35 . principally the same as that of the basaltic komatiites, but a few of the oldest eruptions discharged komatiite lavas. The Kummitsoiva complex, which is composed mainly of amphibole-chlorite rocks, includes a few serpentine-olivine rock interlayers in its lower part.

The eruptions were characteristically explosive and produced an abundance of pyroclastic material. The explosions were caused by the action of gases held in magma. Many of the pyroclasts are scoriaceous, and some of the lavas contain a few amygdules. Crystal ejecta collected with vitric and lithic ash point to the occurrence of magmatic explosions (Heiken 1974). However, there might have been associated phreatomagmatic explosions as well, because magmas intruded into water-saturated graphitic and calcareous sediments beneath and around the volcano. But the minor amounts of devitrified shards in the fine-grained pyroclastic rocks may be products of steam eruptions when lavas flowed into water.

The eruptions were presumably subaerial, an environmental qualification for the formation of block lavas (Macdonald 1972, p. 68). But blocks with smooth and curved surfaces, 

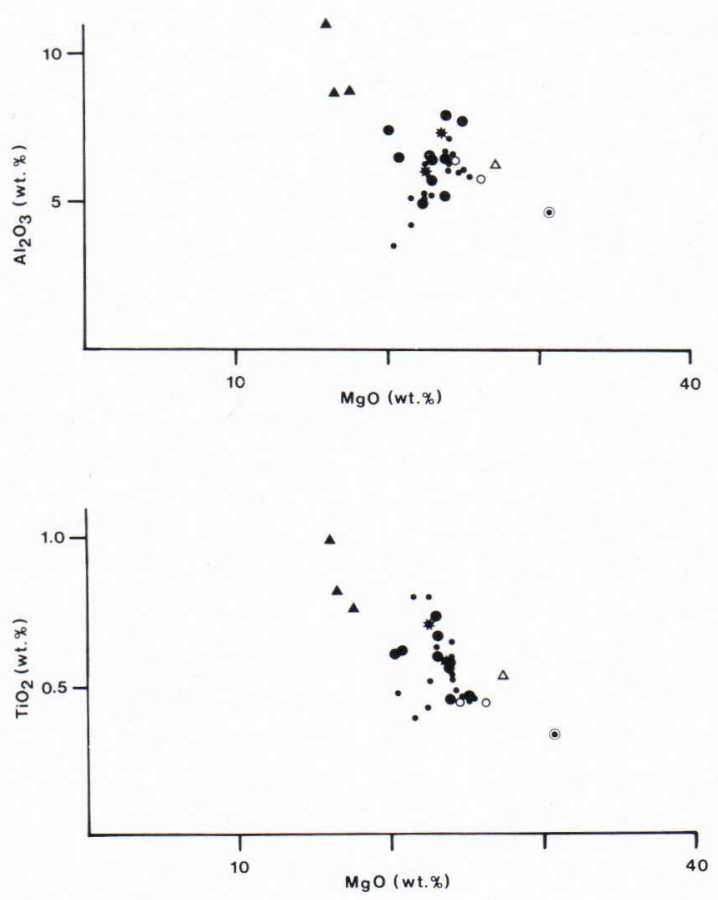

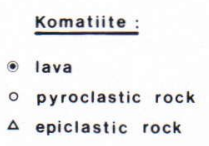

- pyroclastic rock

- epiclastic rock

Fig. 23. $\mathrm{Al}_{2} \mathrm{O}_{3}-\mathrm{MgO}$ and $\mathrm{TiO}_{2}^{-}-\mathrm{MgO}$ diagrams of rocks in the Kummitsoiva complex.

and their partly welded contacts and glassy parts are all typical of block-lava flows coming into contact with water before complete solidification (Macdonald 1972, pp. 96-97). Thus, some block lavas flowed into the littoral zone of the surrounding basin, and a few lava pillows formed with fluidal-shaped flow breccia in their cores. Some lavas intruded into water-saturated tuffaceous strata when pillow breccias were formed (deWit and Stern 1978).

Block lavas and flow breccias originated from a very viscous lava (Macdonald 1972, p. 96). The viscosity of the basaltic komatiite lava might result from its low temperature, which might explain the lack or scarcity of spinifex textures and polygonal jointing. The dearth of spatter-like coarse-grained pyroclasts reflects less viscous lava. The viscosity changed in lavas, however, and some lava flows differentiated gravitationally and formed cumulates in their lower parts. The fluidal-shaped fine ejecta observed are typical of ash generated from highly fluidal lava (Heiken 1974).

Table 4. XRF analyses of serpentine-olivine rocks, originally lavas, fine-grained ejecta and epiclastic debris in the Kummitsoiva komatiite complex. Analysed by Väinö Hoffrén of the Geological Survey of Finland, Espoo.

\begin{tabular}{lrrrr}
\hline wt. \% & \multicolumn{1}{c}{31} & \multicolumn{1}{c}{32} & \multicolumn{1}{c}{33} & \multicolumn{1}{c}{34} \\
\hline $\mathrm{SiO}_{2}$ & 41.63 & 39.22 & 42.32 & 40.10 \\
$\mathrm{Al}_{2} \mathrm{O}_{3}$ & 4.65 & 5.74 & 6.35 & 6.25 \\
$\mathrm{Fe}_{2} \mathrm{O}_{3} *$ & 9.93 & 14.34 & 11.02 & 14.04 \\
$\mathrm{MgO}$ & 30.77 & 26.24 & 24.52 & 27.26 \\
$\mathrm{CaO}$ & 2.63 & 4.32 & 7.36 & 2.49 \\
$\mathrm{Na}_{2} \mathrm{O}$ & .87 & .77 & .82 & .64 \\
$\mathrm{~K}_{2} \mathrm{O} * *$ & .00 & .00 & .00 & .00 \\
$\mathrm{MnO}_{\mathrm{TiO}}$ & .18 & .27 & .22 & .15 \\
$\mathrm{P}_{2}^{-} \mathrm{O}_{5}$ & .33 & .44 & .44 & .52 \\
\hline $\mathrm{Total}^{*}$ & .00 & .00 & .03 & .00 \\
\hline $\mathrm{CaO} / \mathrm{Al}_{2} \mathrm{O}_{3}$ & 90.99 & 91.34 & 93.08 & 91.45 \\
$\mathrm{Al}_{2} \mathrm{O}_{3} / \mathrm{TiO}_{2}$ & .57 & .75 & 1.16 & .40 \\
\hline
\end{tabular}

* total $\mathrm{Fe}$ as $\mathrm{Fe}_{2} \mathrm{O}_{3}$

** detection limit for $\dot{\mathrm{K}}_{2} \mathrm{O}$ is 0.1 wt. \%

Samples:

31. Cumulate lava containing olivine and bastitic phenocrysts, coordinates: $\mathrm{x}=7454.00, \mathrm{y}=$ 543.35 .

32. Lithic-vitric tuff composed of fluidal-shaped ejecta and olivine and pyroxene crystals, coordinates: $\mathrm{x}=7459.66, \mathrm{y}=546.84$.

33. Lithic-crystal tuff composed of fluidal-shaped ejecta and olivine and pyroxene crystals (in Figure 20), coordinates: $\mathrm{x}=7458.64, \mathrm{y}=545.28$.

34. Epiclastic volcanic sandstone containing serpentine clasts (in Figure 21), coordinates: $x=$ $7454.00, \mathrm{y}=536.84$. 
The komatiite lavas, which form thin flowtextured interlayers grading into accumulations of fluidal-shaped ejecta, may be fluidal.

The block lavas grade into poorly sorted and crudely stratified pyroclastic rocks such as volcanic mudflows or lahars associated with autobrecciated lavas (Williams and McBirney 1979, pp. 171-178). Abrasion due to rolling may explain the general roundness of the coarse-grained pyroclasts. Some of the ejecta were redeposited as well-rounded and moderately sorted fragments.

The pyroclastic material, mainly lithic and vitric, also contains accessory ejecta such as fragments of older lithified lavas forming pyroclastic breccias. Accidental ejecta and epiclastic volcanic debris are present, too.

The greater the distance from a volcanic vent, the more fine-grained, sorted and stratified the lahars become (Williams and McBirney 1979, p. 177). Tuffs, lapilli tuffs and epiclastic volcanic debris in the outer zone of the Kummitsoiva complex were transported into water and deposited alternately with euxinic and epiclastic sediments. Smallscale scour-and-fill structures, ripple marks and small-scale cross-bedding developed in shallow water. But the thick massive beds and intraclasts in them require the presence of high-velocity currents (Reineck and Singh 1980, p. 130). Thick, massive coarse-grained tuff beds alternating with laminated finegrained tuff beds resemble the large-scale sedimentary structures described by Fiske (1963) from subaqueous pyroclastic flows deposited by turbidity currents. Slump structures are common in such an environment (Fiske 1963). The bottom of the Kummitsoiva complex slumped together with the upper part of the graphitic slate zone beneath the komatiite. The upper jaspilitic iron ore at Jauratsi and the surrounding sulphide slates also slumped and belonged to the same softsediment deformation zone. Therefore, a marked time interval did not exist between the accumulation of iron-rich sediments and the explosive komatiite volcanism. What is more, the circular facies pattern of the Jauratsi iron ores around the Kummitsoiva volcanic vent (Fig. 26a), and the iron ore (Lehto and Niiniskorpi 1977) in the immediate vicinity of the komatiitic neck at Tuohivaara indicate that the Jauratsi iron ores were associated with the ultramafic volcanism and preceded the komatiite eruptions.

The slumping of strata and the reworking of volcanic debris suggest violent eruptions.

The existence of lavas principally in the middle of the Kummitsoiva complex and other internal volcanic patterns around the volcanic vent (Fig. 24) indicate that the Kummitsoiva complex was originally a large isolated volcano. It was located at the margin or on an island of an interior basin in which sediments of the black-shale »restricted basin» association occur (Krumbein and Sloss 1963, p. 506). The Kummitsoiva volcano was continental because block lavas associated with large volcanic cones have a marked correlation with a continental environment (Macdonald 1972, p. 93). But some of the volcanic material, which erupted through the subaerial volcano, reached the littoral zone of the surrounding basin.

The satellitic komatiites at Känespella and Tuohivaara erupted through separate volcanic vents in a linear pattern with the Kummitsoiva volcano.

\section{Paleotectonic position}

According to the alignment of the komatiitic vents (Fig. 25), a fault, coeval with the euxinic-epiclastic sedimentation existed immediately before the explosive komatiite volcanism. The fault continued in a northwesterly direction including, for instance, the volcanic vent of another pyroclastic koma- 


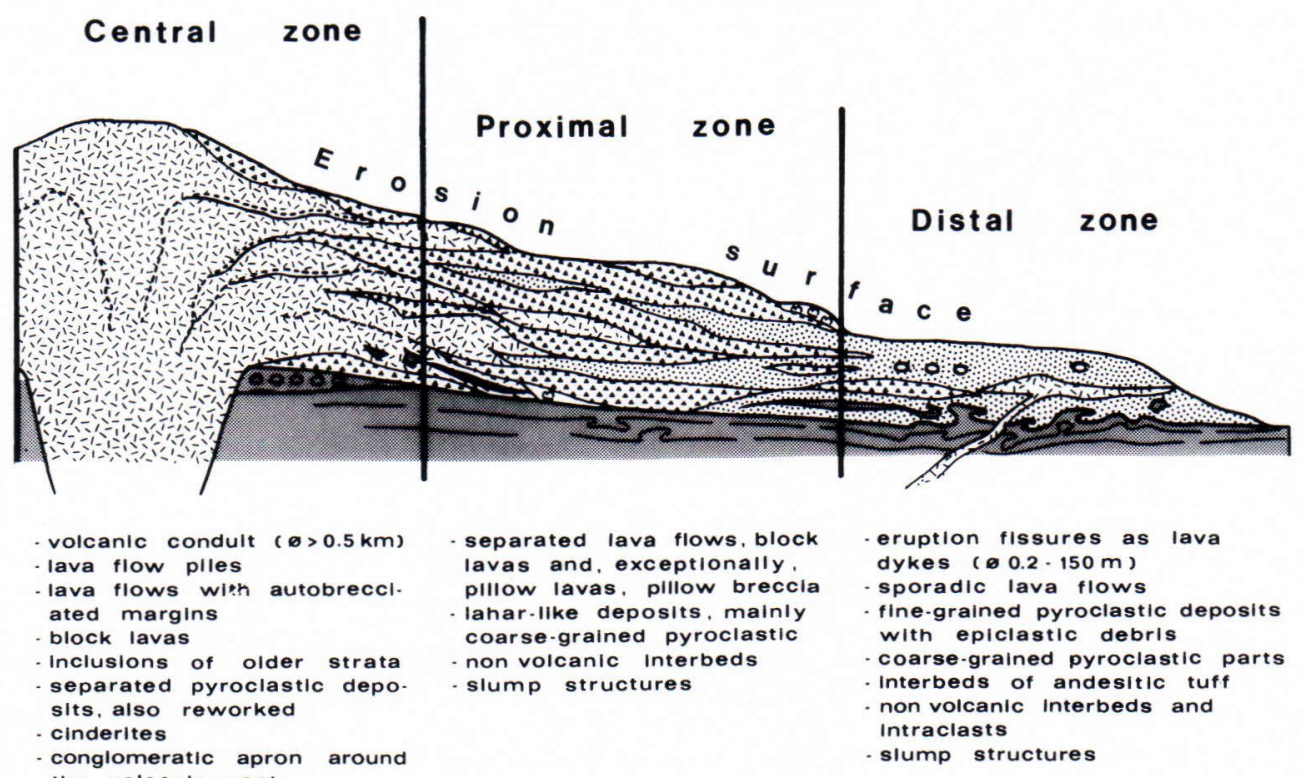

the volcanic vent

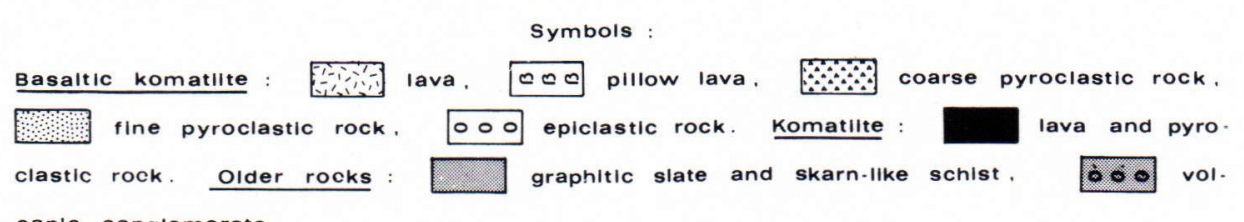

canic conglomerate

Fig. 24. The Kummitsoiva komatiite complex divided into internal volcanic zones related to a large central-vent volcano according to Williams and McBirney (1979, pp. 312-313). The characteristic features of the zones are discussed in the text.

tiite (Saverikko 1983). The fault probably also extended in a southeasterly direction to include a volcanic centre in the PaanajärviKuolajärvi area, U.S.S.R. (Kulikov et al. 1980). From there it joined up with a deep fault in a southeasterly direction in Karelia, U.S.S.R. (Svetov 1980). Thus, the explosive komatiite volcanism took place through a large-scale geotectonic fault in a northwest-southeasterly direction. The paleotectonic fault remained a tectonic line and continued to feed magmas during the Karelian sedimentation (Svetov 1980). It also contains a younger granite dome that belongs to the granites dated to $1800 \mathrm{Ma}$ (Lauerma
1982) in the vicinity of the Kummitsoiva area (Fig. 25).

Displacements between the blocks separated by the coeval fault can be inferred from the thickness of the graphitic slate zone beneath the Kummitsoiva komatiite complex. The graphitic stratum on the northeastern side of the fault is $0-20 \mathrm{~m}$ thick, but thicknesses on the opposite side of the fault observed in diamond drilling are $200-300 \mathrm{~m}$. The southwestern block, therefore, subsided in relation to the northeastern block during the euxinic-epiclastic sedimentation stage in the interior basin. According to the relation between water depth and iron ore facies 


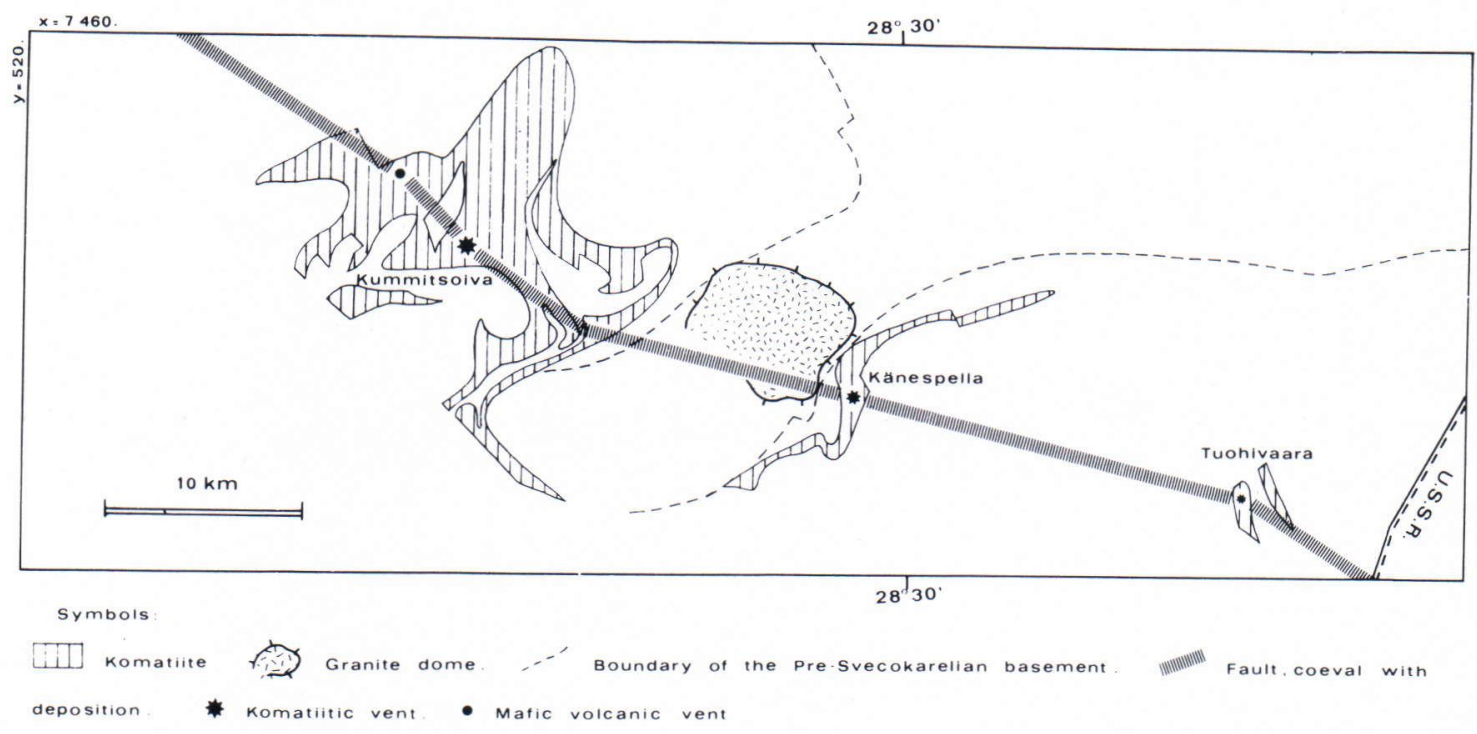

Fig. 25. Alignment of the volcanic conduits and the inferred coeval fault in the Jauratsi and Salla greenstone belts.

(James 1954) applied to the facies pattern of the Jauratsi iron ores (Fig. 26a), the southwestern block or the Jauratsi fault block, may have been tilted westwards (Fig. 26b). This is also suggested by the scarcity of graphitic slates on the southeastern margin of the Jauratsi fault block near the PreSvecokarelian basement. The lack of a graphitic slate zone elsewhere in the Jauratsi fault block is probably due to the paleotopography which may have been the result of internal faults in the block. The 150-m-thick komatiite joint in a southwesterly direction (Fig. 26a) might be one of the fault fissures in the fault set.

Another paleotectonic fault may exist trending from the Kummitsoiva hill toward the northeast. The concentration of serpentine-olivine rocks in the northernmost part of the Kummitsoiva complex and away from the central-vent paleovolcano on Kummitsoiva shows that the komatiite lavas erupted through anorther volcanic conduit or a fis- sure situated in the northernmost part of the complex. The basaltic komatiite lavas partly covered by pyroclastic rocks (Fig. 4) in the middle of the complex are also elongated in a northeasterly direction. The existence of the fault fissure might explain the presence of a separate amphibole-chlorite rock (Mikkola 1937) on the northern side of the area investigated. The pyroclastic exposure is about $1 \mathrm{~km}$ wide and $30 \mathrm{~km}$ long (Heikki Juopperi, pers. commun. 1983) and lies in the middle of the Jauratsi greenstone belt.

\section{Conclusions}

Explosive komatiite volcanism in the Jauratsi and Salla greenstone belts (Gaál et al. 1978) in the eastern part of the schist area of central Lapland was preceded by an euxinic sedimentation stage during which geotectonic faulting took place in a northwesterly direction, and the Jauratsi fault 


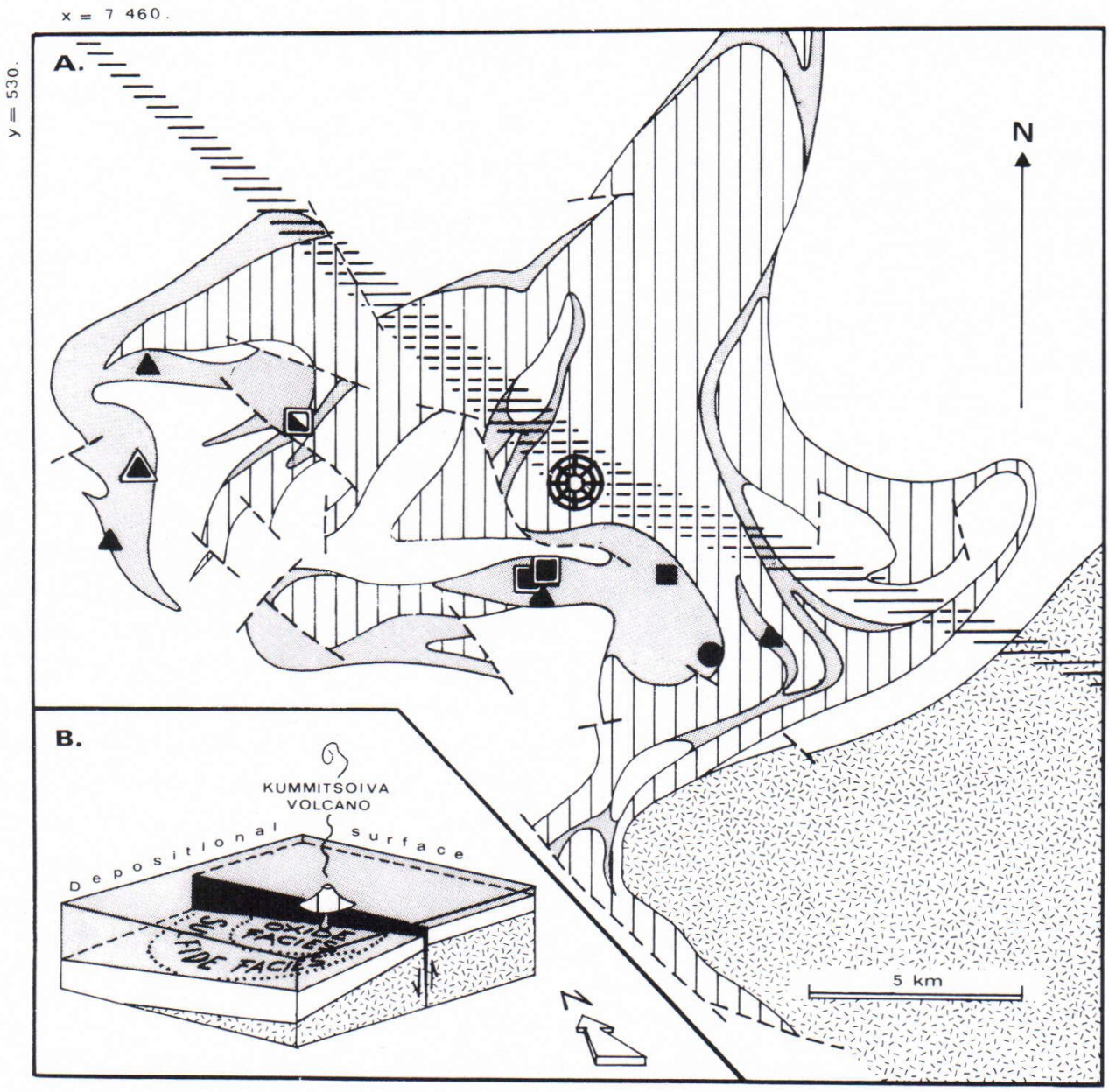

Symbols

$\Pi$ प Kummitsoiva komatiite complex. $\square$ Graphitic slate and skarn-like

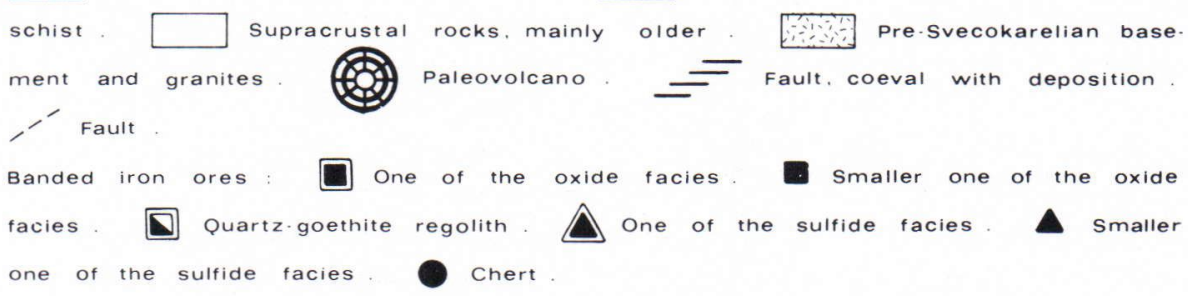

Fig. 26. A: Mutual position of the Kummitsoiva paleovolcano, the main banded iron ores and the coeval fault in the Jauratsi greenstone belt. B: Simplified block diagram based on the thickness of the graphitic slate zone and a facies pattern of the Jauratsi iron ores. 
block, for instance, subsided about $200 \mathrm{~m}$. The komatiite eruptions were preceded by the accumulation of iron ore deposits during the final stage of the euxinic-epiclastic sedimentation. The komatiitic vents were probably located on a coeval fault line in the same places as the feeders of the jaspilitic iron ores.

Paleogeographically, the komatiitic vents were located along the margin or on islands of interior basin in a continental environment. The Kummitsoiva komatiite complex was originally a large isolated volcano that erupted through a volcanic conduit $(\emptyset>$ $0.5 \mathrm{~km}$ ) and a fissure net, whereas the komatiite satellites at Känespella and Tuohivaara were smaller volcanic deposits that erupted through separate volcanic vents $\left(\begin{array}{ll}\emptyset & 20-\end{array}\right.$ $350 \mathrm{~m}$ ).

The ultramafic magma was very viscous, probably because of its low temperature, a fact which explains the abundance of autobrecciated lavas such as flow breccias and block lavas. The predominance of pyroclastic rocks indicates the characteristic explosive acitivity of the eruptions that caused slumping and reworking of older sediments.

The eruptions were principally magmatic explosions, although the likelihood of phreatomagmatic explosions cannot be discounted. Steam eruptions might have been associated with the explosions when lavas flowed into water.

The ultramafic lavas emerged in various phases consisting of several eruptions. Their chemical composition changed during the initial phases, at least in the Kummitsoiva komatiite complex. The bulk of the complex and the komatiite satellites as a whole are amphibole-chlorite rocks, originally basaltic komatiites. The lower part of the complex, however, contains a few serpentine-olivine rock interlayers of komatiites proper.

Erosional periods that occurred during intervals between the komatiite eruption phases produced epiclastic komatiite debris. Intermediate volcanic material erupted during earlier intervals, forming narrow andesitic tuff interlayers in the lower parts of the exposures. As indicated by a mafic (not analysed) volcanic neck intersecting the Kummitsoiva komatiite complex, intermediate or mafic volcanism continued after the komatiite eruptions.

The ultramafic lavas erupted in a subaerial environment, but some block lavas flowed into the littoral zone of the surrounding interior basin. Autobrecciated lavas grade into coarse-grained pyroclastic rocks such as agglomerates, pyroclastic breccias and lapillistones. They are loosely packed, poorly sorted, crudely stratified and resemble lahars. Coarse-grained ejecta, particularly in the outer zone of the Kummitsoiva complex, grade into fine-grained pyroclastic and epiclastic material deposited in water by turbidity currents. The fine-grained pyroclastic rocks are tuffs and lapilli tuffs; the epiclastic rocks are volcanic silts and sands and very crude conglomeratic accumulations.

The primary mineral species are seldom visible. In spite of recrystallization, the amphibole-chlorite rocks exhibit relicts of pyroxene and, possibly, of olivine. Devitrified volcanic glass droplets have also been preserved. The pyroclasts are lithic and vitric, and the crystal ejecta consist of olivine and pyroxene. The epiclastic debris contains spinifex-textured grains among other clasts. The serpentine-olivine rocks include olivine and relicts of pyroxene in lavas. The ejecta in the pyroclastic rocks are lithic-vitric and contain olivine and pyroxene crystals. Also present are epiclastic rocks with serpentine clasts.

The amphibole-chlorite rocks are basaltic komatiites displaying no systematic variations in chemical composition between lavas and pyroclastic rocks. They grade from ultramafic to mafic rocks, $\left(\mathrm{SiO}_{2} 39.42-49.52 \mathrm{wt} . \%\right)$ and their $\mathrm{MgO}$ contents are moderate (20.15- 
25.41 wt.\%). The serpentine-olivine rocks, the komatiites proper, have $\mathrm{SiO}_{2}$ contents ranging from 39.22 wt.\% to 42.32 wt.\% and $\mathrm{MgO}$ contents from 24.52 wt.\% to 30.77 wt.\%. Even though the chemical data are not sufficient, the komatiites of pyroclastic origin and the basaltic komatiites seem to overlap in composition. The epiclastic rocks, however, both komatiites and basaltic komatiites, are depleted in $\mathrm{MgO}$ but enriched in $\mathrm{SiO}_{2}, \mathrm{Al}_{2} \mathrm{O}_{3}$ and $\mathrm{TiO}_{2}$.

The komatiites investigated represent the latest marked volcanic stage in the Jauratsi and Salla greenstone belts. The earlier volcanic stages are manifested, in stratigraphic order, by an uralitic greenstone, the Salla greenstone complex composed of mafic metavolcanic rocks with intermediate and felsic interlayers and ultramafic parts, and by an amphibolite that is an iron-rich tholeiitic basalt. The komatiites belong to the upper part of the Lapponian supracrustal sequence, which is regarded as either Archean or Proterozoic in age (Silvennoinen et al. 1980; Simonen 1980).

\section{References}

Arndt, Nicholas and Brooks, Christopher, 1980. Komatiites. Penrose Conference Report. Geology $8,155-156$.

-, N.T. and Nisbet, E.G., 1982. What is a komatiite? In: Arndt, N.T. and Nisbet, E.G. (Editors) Komatiites. George Allen \& Unwin. London. 19-27.

Auvray, B., Blais, S., Jahn, B.-M. and Piquet, D., 1982. Komatiites and the komatiitic series of the Finnish greenstone belts. In: Arndt, N. T. and Nis bet, E. G. (Editors) Komatiites. George Allen \& Unwin. London. 131-146.

Blais, S., Auvray, B., Cardevila, R., Jahn, B. M., Bertrand, J. M. and Hameurt, J., 1979. The Archaean greenstone belts of Karelia (eastern Finland) and their komatiitic and tholeiitic series. In: Windley, B. and Naqvi, S. M. (Editors) Developments in Precambrian Geology, I. Ar-
Acknowledgements. I thank Dr. Juhani Nuutilainen, Chief of the Exploration Department of Rautaruukki Oy, who interested me in the pyroclastic komatiites in Finnish Lapland and put the company's geological material at my disposal.

The investigation was aided financially by grants from the Finnish Academy of Sciences (project 24/001; Leader, Dr. Tapio Koljonen) and from the Outokumpu Oy Foundation. Professor Ilmari Haapala, of the University of Helsinki, actively supported the investigation, and Dr. Kari Kinnunen, of the Geological Survey of Finland, assisted with the petrographic work and with many discussions. Mr. Kari Airas and Mr. Osmo Inkinen, Chief Geologists of Lapin Malmi, were always ready with a sympathetic ear and they gave me any geological material I required.

I also thank my former co-workers, Miss Maggie McColl, of the University of Waterloo in Manitoba, and Mr. Tuomo Manninen, of the Geological Survey of Finland, with whom I worked while employed by Rautaruukki Oy in 1979-80.

Finally, I am very grateful to Kalervo Rankama, Emeritus Professor of the University of Helsinki, for the help he gave me in preparing a written version of my investigation.

chaean Geochemistry. Elsevier. AmsterdamOxford-New York. 87-107.

Cook, E. F., 1965. Stratigraphy of Tertiary volcanic rocks in eastern Nevada. Nev. Bur. Mines Report, 11. (referred to in Heiken 1974).

deWit, Maarten J. and Stern, Charles, 1978. Pillow talk. J. Volcanol. Geotherm. Res., 4, 55-80.

Fisher, Richard V., 1961. Proposed classification of volcanoclastic sediments and rocks. Geol. Soc. Am. Bull. 72, 1409-1414.

-, 1966. Rocks composed of volcanic fragments and their classification. Earth-Sci. Rev. 1, 287298.

Fiske, Richard S., 1963. Subaqueous pyroclastic flows in the Ohanapecosh Formation, Washington. Geol. Soc. Am. Bull. 74, 391-406.

Gaál, Gabor, Mikkola, Aimo and Söderholm, Bengt, 1978. Evolution of the Archean crust in Finland. Precambrian Res. 6, 199-215.

Hanski, Eero, 1980. Komatiitic and tholeiitic metavolcanics of the Siivikkovaara area in the Ar- 
chean Kuhmo greenstone belt, eastern Finland. Bull. Geol. Soc. Finland 52, 1, 67-100.

Heiken, Grant, 1974. An atlas of volcanic ash. Smithsonian Contrib. Earth Sci. 12.

James, H. L., 1954. Sedimentary facies of iron formation. Econ. Geol. 49, 235-293.

Krumbein, W. C. and Sloss, L. L., 1963. Stratigraphy and Sedimentation. 2nd Edition. W. H. Freeman and Company. San Francisco and London.

Kulikov, V. S., Galdobina, L. P., Voinov, A. S., Golubev, A. V., Kashpirov, S. I., Polehovsky, Yu. S. and Svetov, A. P., 1980. Jatulian geology of the Paanajärvi-Kuolajärvi synclinorium. In: Silvennoinen, Ahti (Editor) Jatulian Geology in the eastern Part of the Baltic Shield. Proceedings of a Finnish-Soviet Symposium held in Finland, 21st-26th August, 1979. The Committee for Scientific and Technical Co-operation between Finland and the Soviet Union. Rovaniemi, 1980. 73-96.

Lauerma, Raimo, 1967a. Suomen geologinen kartta. Kallioperäkartta. Geological Map of Finland. Pre-Quaternary Rocks. Lehti-Sheet-4621+ 4623-Salla. 1: 100000 . Geological Survey of Finland. Espoo.

-, 1967b. Suomen geologinen kartta. Kallioperäkartta. Geological Map of Finland. Pre-Quaternary Rocks. Lehti-Sheet-3643-Kursu. $1: 100000$. Geological Survey of Finland. Espoo.

,- 1982 . On the ages of some granitoid and schist complexes in northern Finland. Bull. Geol. Soc. Finland 54, 1-2, 85-100.

Lehto, Tapio and Niiniskorpi, Veikko, 1977. Pohjois- ja Itä-Suomen rautamuodostumat. Summary: The iron-formations of northern and eastern Finland. Tutkimusraportti-Rep. Invest. 22, Geological Survey of Finland. Espoo.

Macdonald, Gordon A., 1972. Volcanoes. PrenticeHall, Inc. Englewood Cliffs. New Jersey.

Manninen, Tuomo, 1981. Savukosken Akanvaaran alueen geologiasta. M.Sci. Thesis, Institute of Geology and Mineralogy, University of Turku.

Mielikäinen, Pekka, 1979. Suomen geologinen kartta. Kallioperäkartta. Geological Map of Finland. Pre-Quaternary Rocks. Lehti-Sheet3642-Pelkosenniemi. 1: 100000 . Geological Survey of Finland. Espoo.

Mikkola, Erkki, 1937. Suomen geologinen yleiskartta. Kivilajikartta. General Geological Map of Finland. Pre-Quaternary Rocks. LehtiSheet-(C 7)-Sodankylä. 1:400 000. Geological
Commission of Finland. Helsinki. [Now: Geological Survey of Finland. Espoo.]

-, 1941. Suomen geologinen yleiskartta. Kivilajikartan selitys. Lehdet-Sheets-B 7 - C 7D 7, Muonio-Sodankylä-Tuntsajoki. General Geological Map of Finland. Summary: Explanation to the Map of Rocks. Geological Commission of Finland. Helsinki. [Now: Geological Survey of Finland. Espoo.]

Mutanen, Tapani, 1976. Komatiites and komatiite provinces in Finland. Geologi 28, 49-56.

Nesbitt, R. W., Sun, Shen-Su and Purvis, A. C., 1979. Komatiites: geochemistry and genesis. Can. Mineral. 17, 165-186.

Reineck, H.-E. and Singh, I. B., 1980. Depositional Sedimentary Environments with Reference to Terrigenous Clastics. 2nd, revised and updated Edition. Springer-Verlag. Berlin, Heidelberg, New York.

Rieck, K.-H., Borchert, H. und Anger, G., 1967. Lagerstättenkundliche Untersuchungen am Eisenerzvorkommen Jauratsi in Finnisch Lapland. Bull. Comm. géol. Finlande 226.

Räsänen, Jorma, 1983. Keski-Lapin liuskealueen komatiiteista. English summary. Geologi 35, 25-29.

Saverikko, Matti, 1983. Explosive komatiitic volcanism in Finnish Lapland. Geologi 35, 21-23.

Silvennoinen, A., Honkamo, M., Juopperi, H., Lehtonen, M., Mielikäinen, P., Perttunen, V., Rastas, P., Räsänen, J. and Väänänen, J., 1980. Main features of the stratigraphy of North Finland. In: Silvennoinen, Ahti (Editor) Jatulian Geology in the eastern Part of the Baltic Shield. Proceedings of a Finnish-Soviet Symposium held in Finland, 21st-26th August, 1979. The Committee for Scientific and Technical Cooperation between Finland and the Soviet Union. Rovaniemi 1980, 153-162.

Simonen, Ahti, 1960a. Pre-Quaternary Rocks in Finland. Bull. Comm. géol. Finlande 191.

-, 1960b. Pre-Cambrian stratigraphy of Finland Int. Geol. Congr. 21 Sess., Norden 1960, Part 9, Pre-Cambrian Stratigraphy and Correlations. Copenhagen 1960.

-, 1971. Das finnische Grundgebirge. Geol. Rundsch. 60, 4, 1406-1421.

-, 1980. The Precambrian in Finland. Geol. Surv. Finland Bull. 304.

Svetov, A. P., 1980. The Jatulian volcanism of Karelia. In: Silvennoinen, Ahti (Editor) Jatulian Geology in the eastern Part of the Baltic Shield. Proceedings of a Finnish-Soviet Symposium held in Finland, 21st-26th August, 1979. The 
The Kummitsoiva komatiite complex and its satellites in northern Finland 139

Committee for Scientific and Technical Cooperation between Finland and the Soviet Union. Rovaniemi, 1980. 195-220.

Tröger, W. E., 1967. Optische Bestimmung der gesteinsbildenden Minerale. Teil 2 Textband. E. Schweizerbart'sche Verlagsbuchhandlung. Stuttgart.

Viljoen, M. J., Viljoen, R. P. and Pearton, T. N., 1982. The nature and distribution of Archaean komatiite volcanics in South Africa. In: Arndt, N. T. and Nisbet, E. G. (Editors) Komatiites. George Allen \& Unwin. London. 53-79.

Williams, Howel and McBirney, Alexander, R., 1979. Volcanology. Freeman, Cooper and Company. San Francisco.

Manuscript received, April 11, 1983 